\title{
بـث بـنوان
}

\section{أدب القضاء عند الأحناف \\ وكتاب ابن هازة أنهوذجًا}

إعداد الباحث

أحمد بن علي الفيفي

كلية الاراسات القضائية

وزارة الدفاع

جامعة الملك عبد العزيز

المملكة العربية السعودية 
- IOVA - 
أدب القضاء عند الأحناف

وكتاب ابن مازة أنموذجاً

أحمد بن علي الفيفي.

كلية الدراسات القضائية، وزارة الدفاع، جامعة الملك عبد العزيز، المملكة العربية

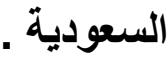

Ahmedemha@hotmail.com : البريد الإكتروني

ملخص :

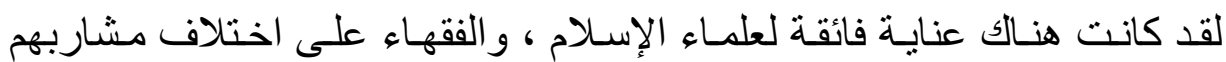

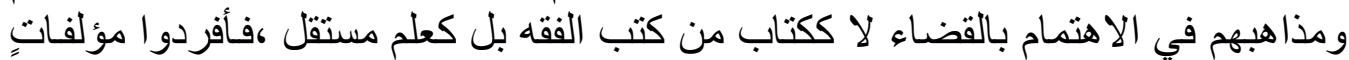

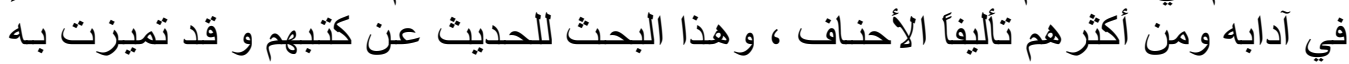

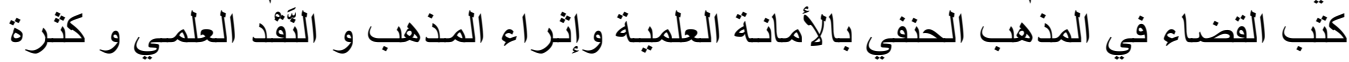

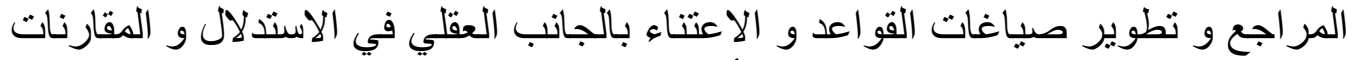

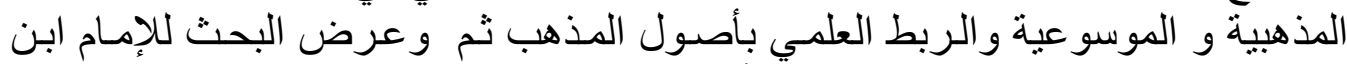

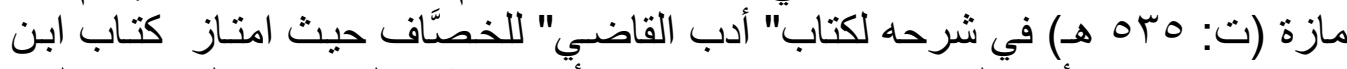

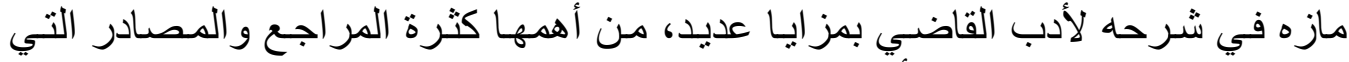

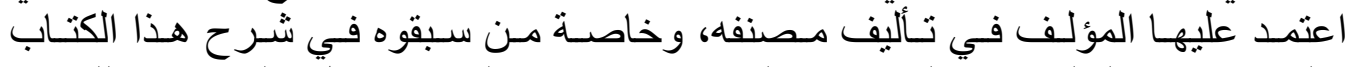

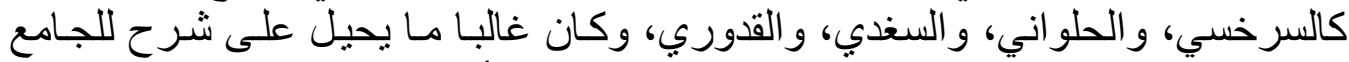

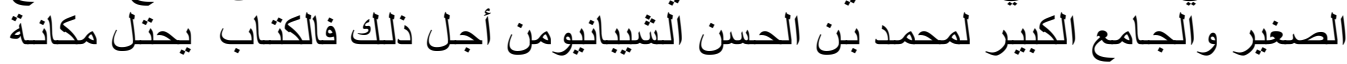

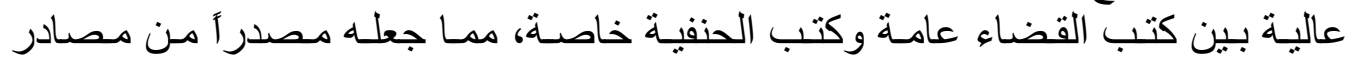
التصنيف لكثير من المصنفين الذين أتو ا بعده، كالسروجي و غيرهاه

الكلمات المفتاحية :أدب القضاء ،الأحناف، كتاب ابن مازة، أنموذجاً . 


\section{The Literature of the judiciary at Al-elahanaf and the book of Ibn Mazah as an model}

\section{College of Judicial Studies, Ministry of Defense, King Abdulaziz University, Saudi Arabia.}

\section{Email: Ahmedemha@hotmail.com}

\section{Abstract:}

There was great care for the scholars of Islam, and the jurists differed in their ways and doctrines in caring for the judiciary, not as a book from the books of jurisprudence but as an independent science, so they singled out literature in his literature and among the most familiar with the Hanafis, and this research is to talk about their books and the books of the judiciary have been distinguished in the Hanafi school with scientific integrity Enriching the doctrine and scholarly criticism, the abundance of references, developing the formulations of the rules, caring for the mental aspect in reasoning, doctrinal and encyclopedic comparisons, and the scientific connection with the origins of the doctrine.

and then presented the research to Imam Ibn Mazah ( $T$ $\therefore$ oro $\mathrm{AH}$ ) in his explanation of the book "Literature of the Judge" for Al-Khasaf, where he excelled a book Ibn Mazeh in explaining The literature of the judge has many advantages, the most important of which are the many references and sources on which the author relied on authoring his work, especially those who preceded him in explaining this book such as Al-Sarkhasi, Al-Halawani, Al-Sughdi and Al-Qaddouri, and he was often referring to an explanation of the small mosque and the great mosque of Muhammad bin Al-Hassan Al-Shaybhanim for that. The book occupies a high position among the judiciary books in general and the Hanafi books in particular, which made it a source of classification for many of the classifiers who came after it, such as Alsrouji and others.

Key words: Literature of the judiciary, Al-elahanaf, The book of Ibn Mazah, A model. 


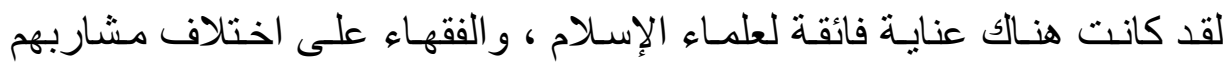

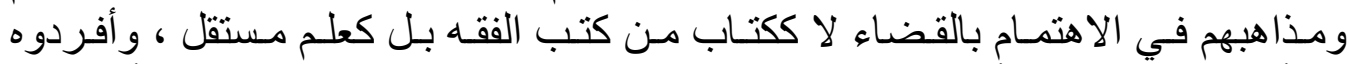

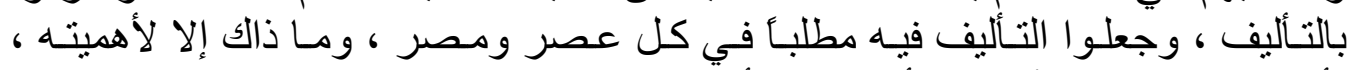

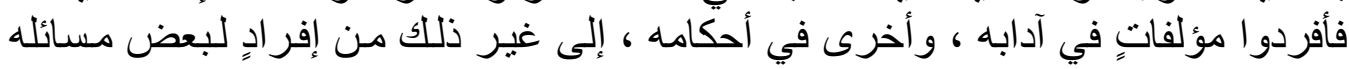

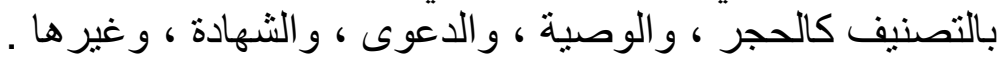

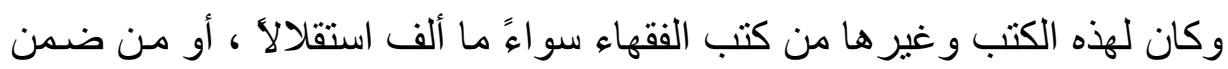

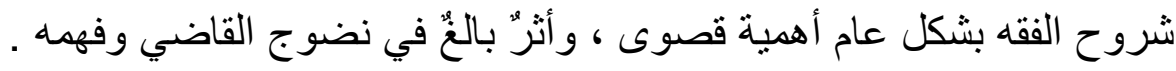

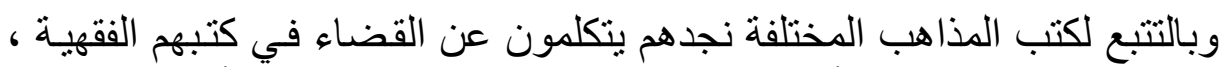

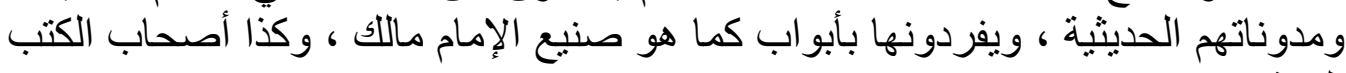

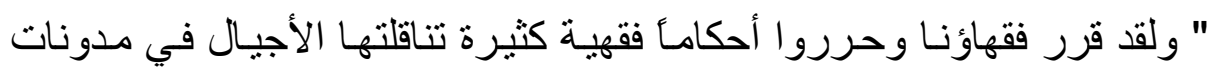

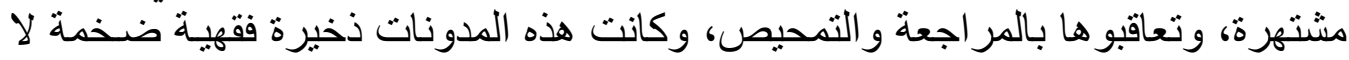

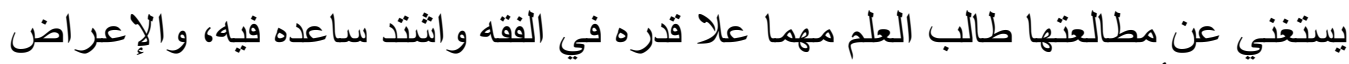

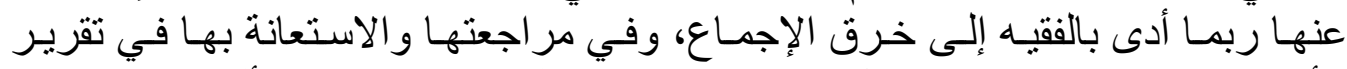

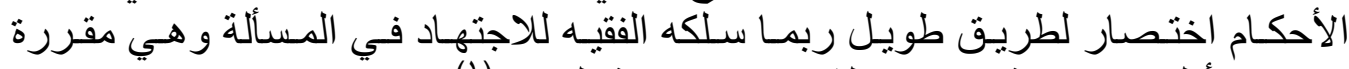

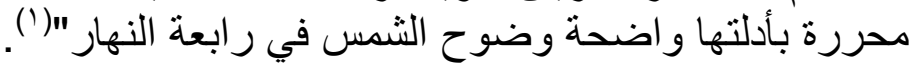
ومن أكثرهم تأليفًا الأحناف ، ور غبت افر ادهم بهذا البحث للحديث عن كتبهم وأخذت شرح ابن مازه انموذجاً ....وبالله التوفيق الأن

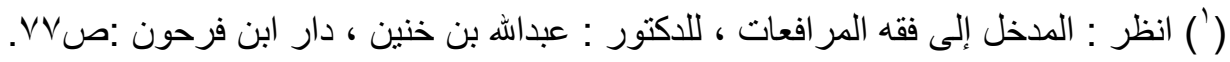




\section{المبمث الأول \\ التأليف لدى السادة الهنفية في أدب القضاك}

\section{المطلب الأول}

\section{نبذه مختصرة عن كتب القضاء في المذهب الهنفي}

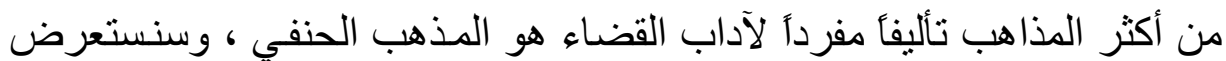

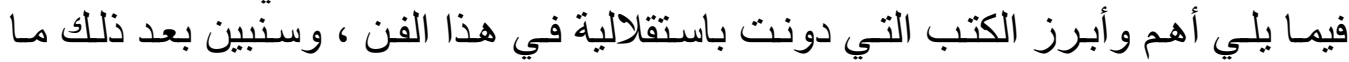

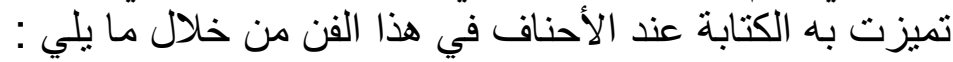
الفرع الأول: كتب القضاء في المذهب الحنفي . للأحنـاف مؤلفـات كثيرة في أدب القضاء ، بـلـ هـ أكثر المـذاهب تأليفـاً مفـرداً لأدب

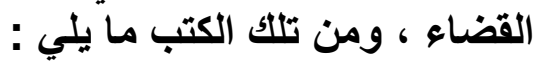

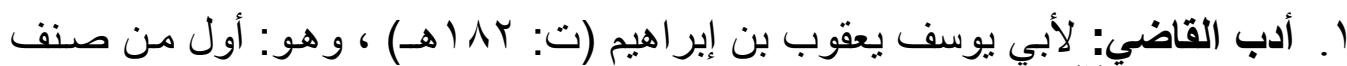

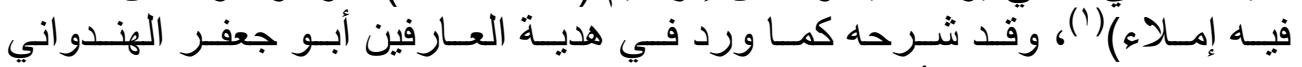

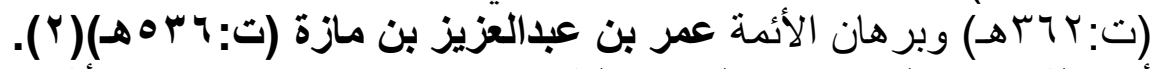

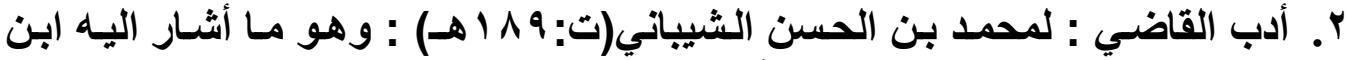

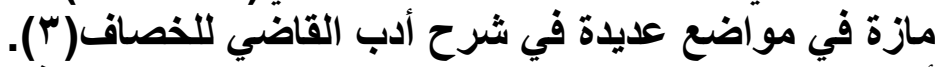

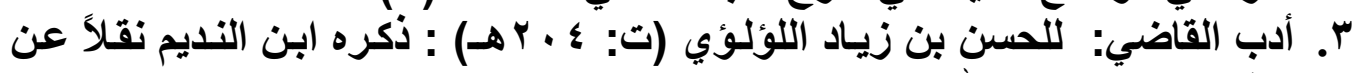

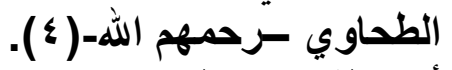

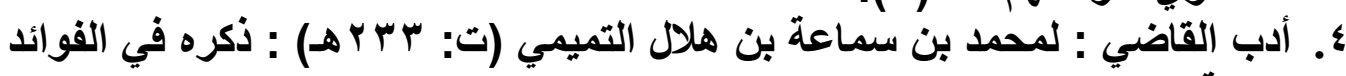

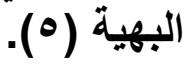

(') انظر : كثف الظنون حاجي خليفة أو الحاج خليفة (ت: V7 • ( هـ) ، الناشـر: مكتبـة المثنى ـ بغداد

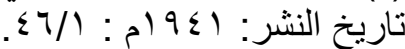

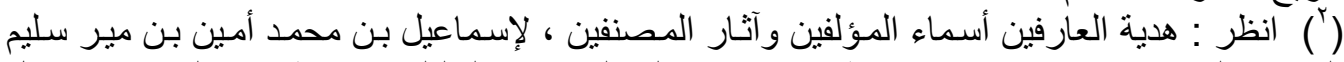

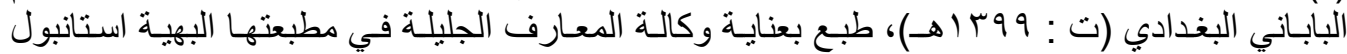

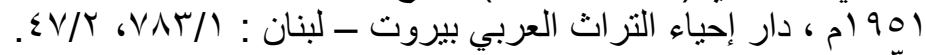

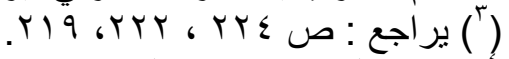

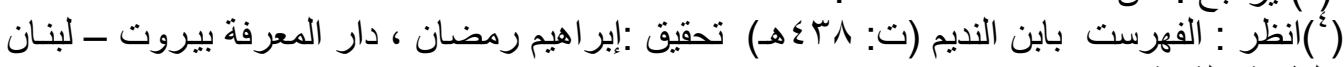

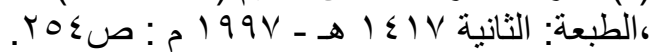

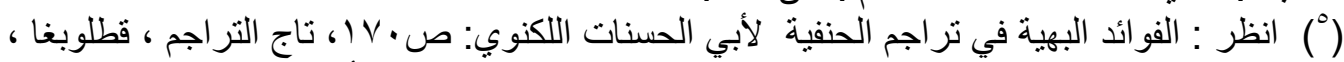

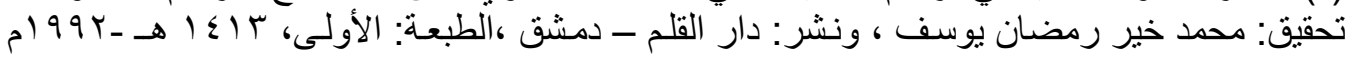




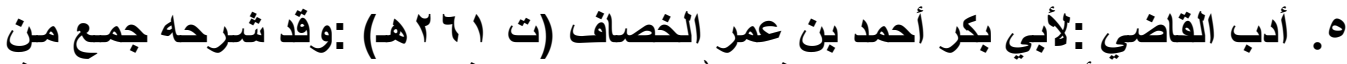

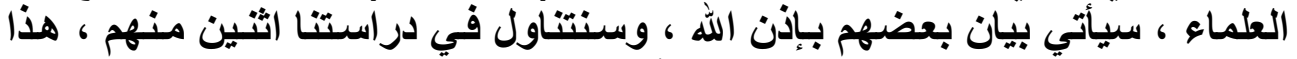

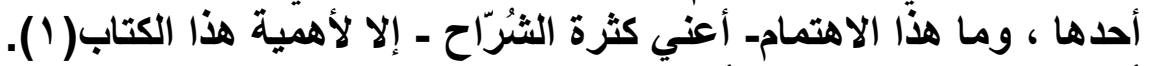

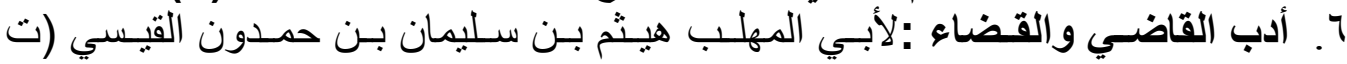

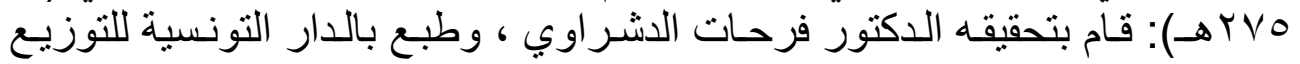

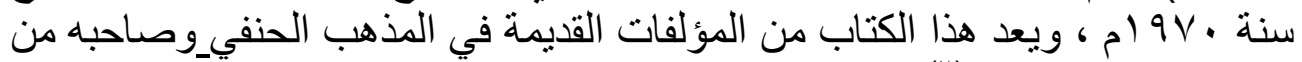

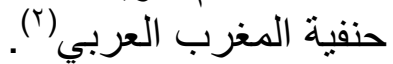

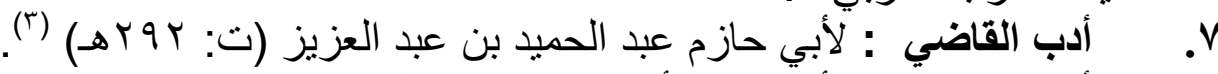

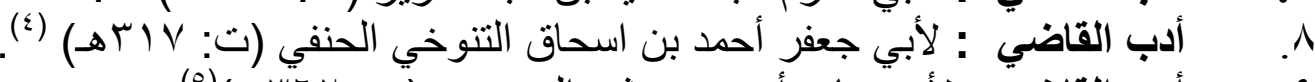

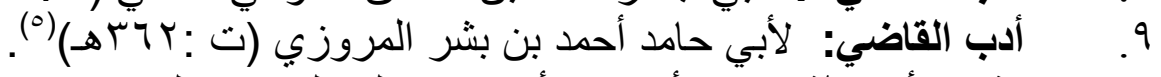

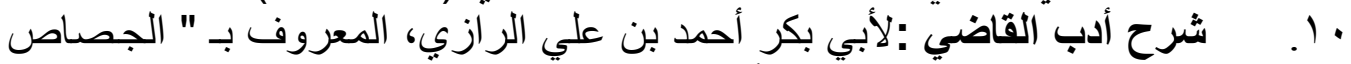

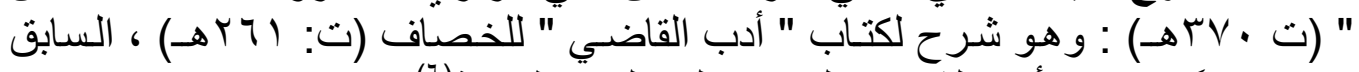

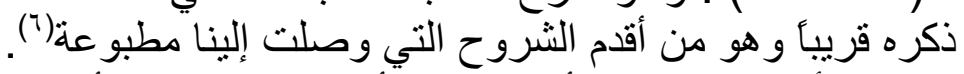

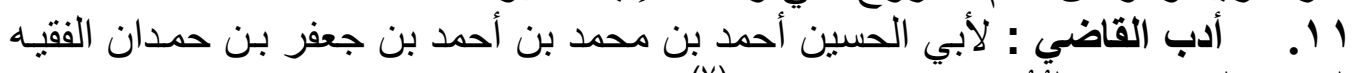

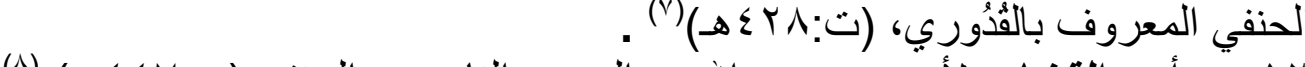

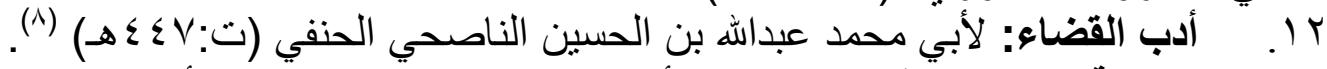

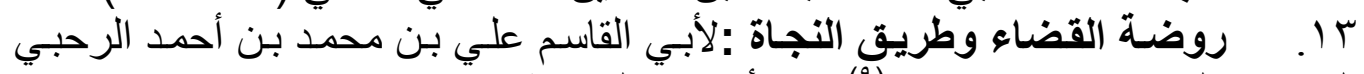

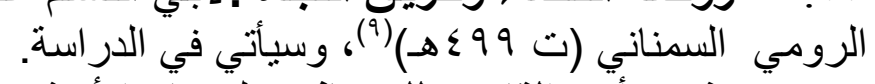

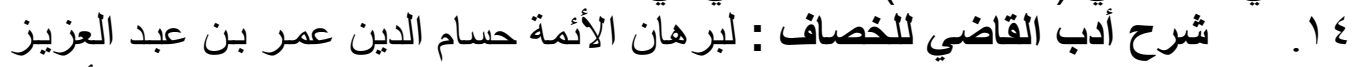

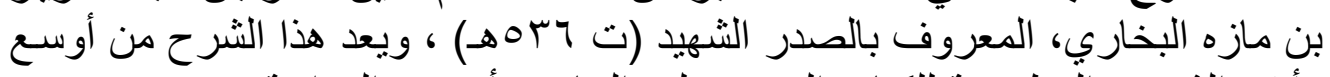

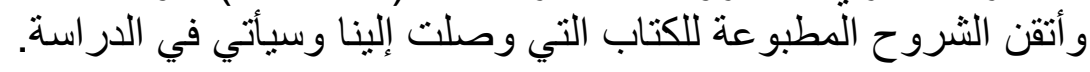

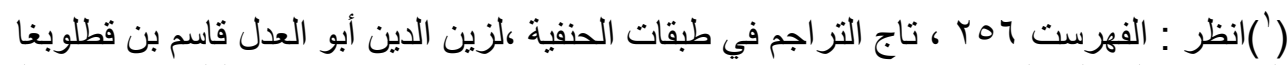

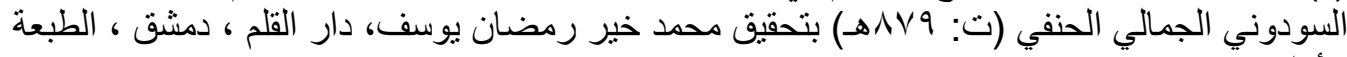

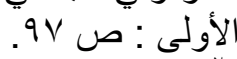

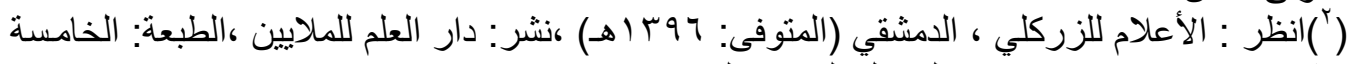

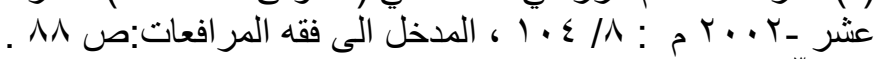

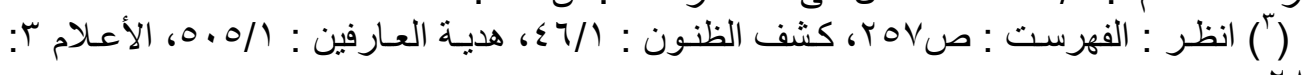

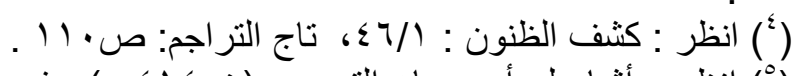

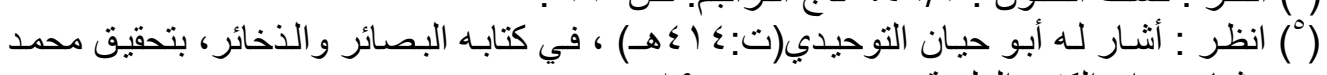

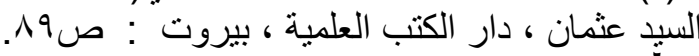

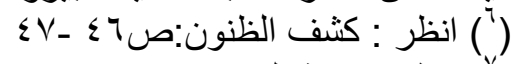

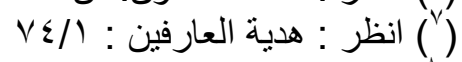

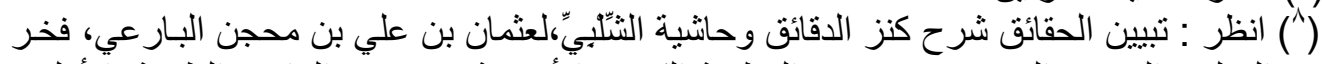

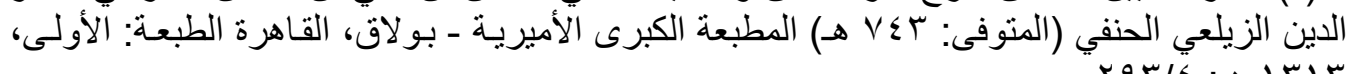

( ) انظر : طبع بتحقيق صلاح الدين الناهي وسيأتي، وقد نسبه في كثف الظنون للزيلعي وهو خطأ 
10. أدب القاضي : لعمر بن شمس الأئمة بكر بن محمد بن علي الزرنجري ، عمـاد

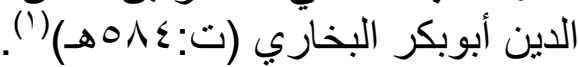

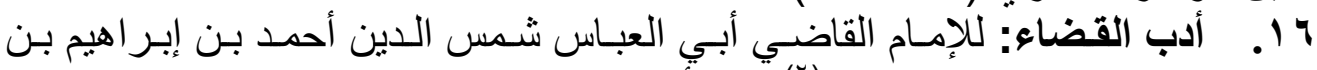

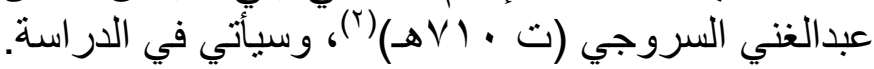

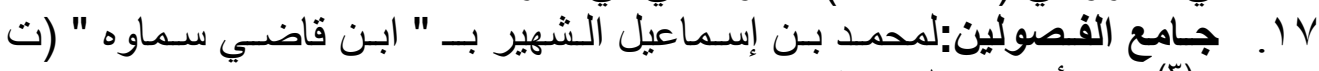

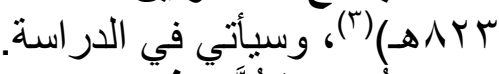

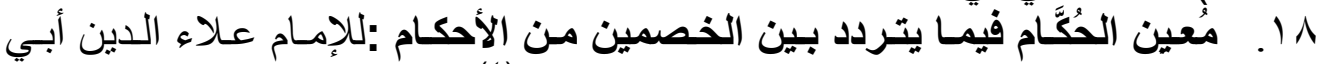

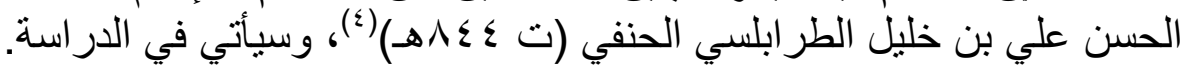

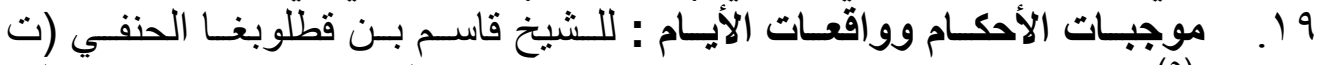

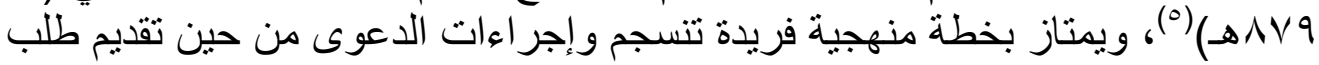

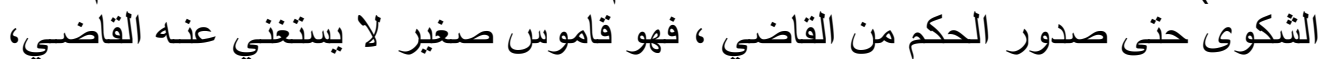

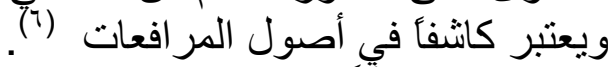

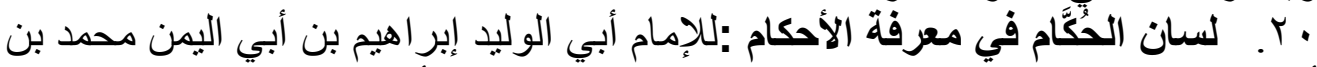

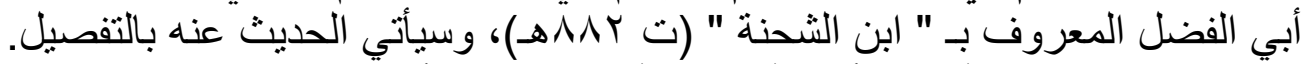

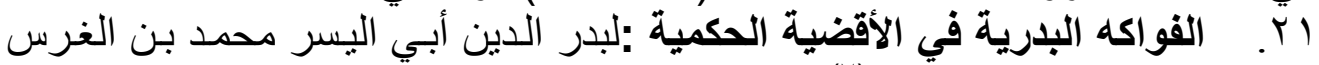

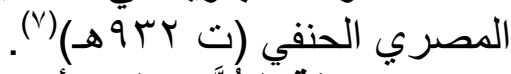

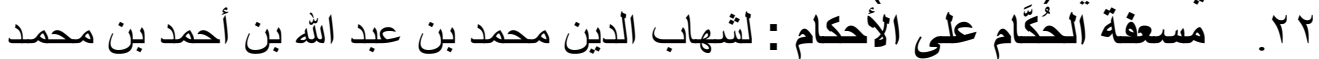

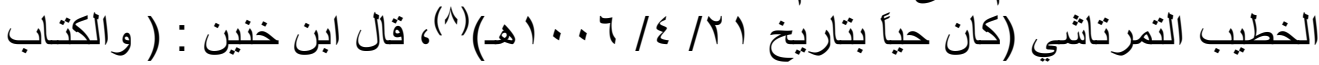

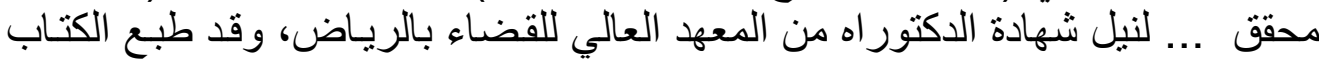

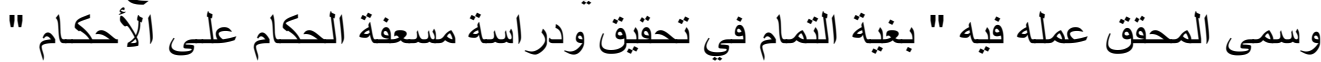

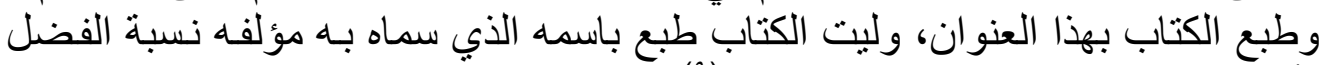

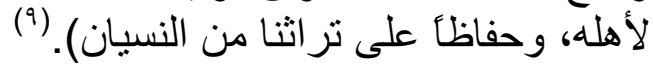

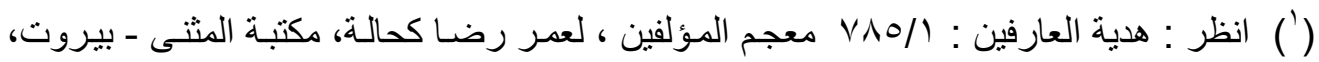

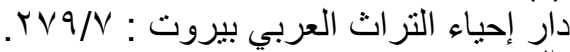

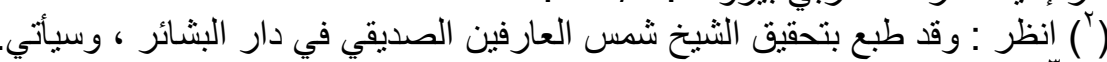

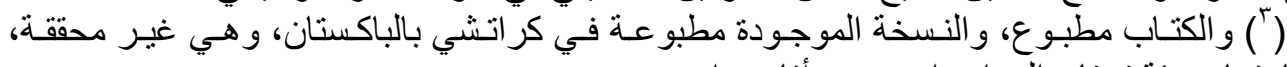

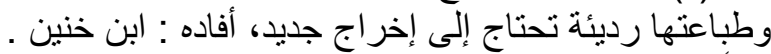

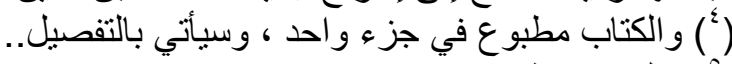

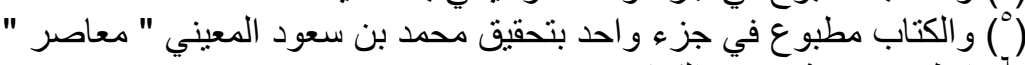

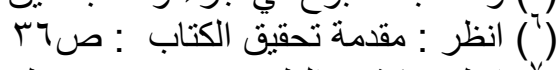

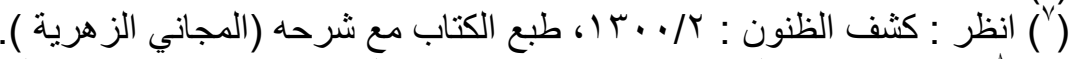

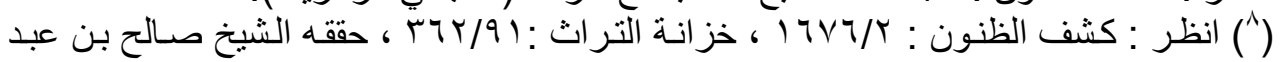

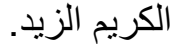




\section{الفرع الثاني: ما تميزت به كتب القضاء في المذهب الحنفي.}

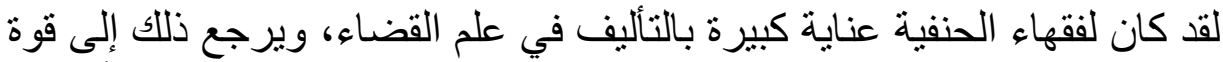

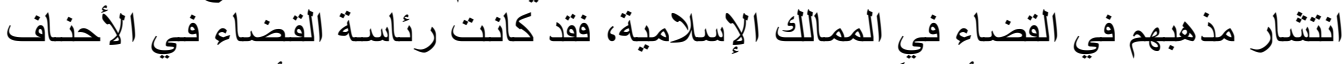

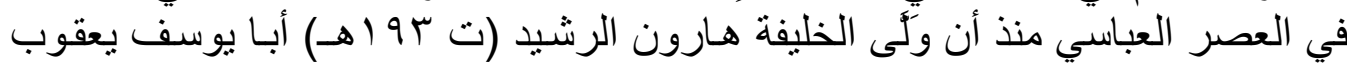

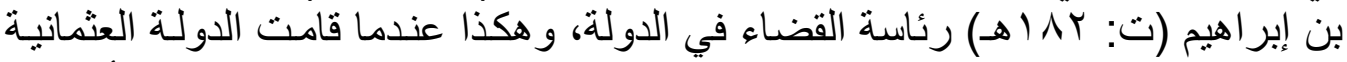

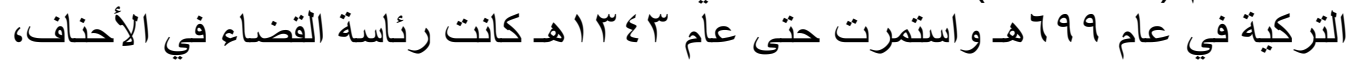

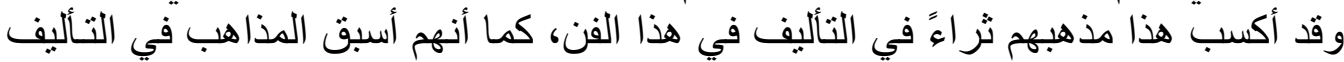

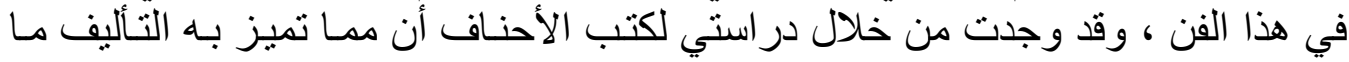
:يلي :

ا ـ الأمانة العلمية: حيث نسبة القول لصاحبه الذي قال به.

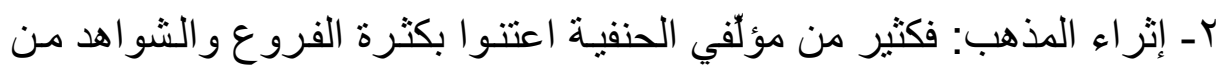

فروع الدذهب، ويرجع ذلك لطريقة الحنفية الخاصة في استتباط القو اعد من الفروع.

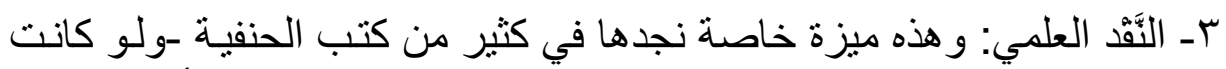

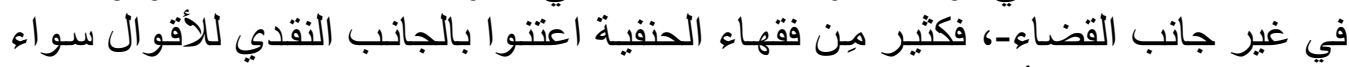
بالنصوص الثر عية أو المعاني المعقولة.

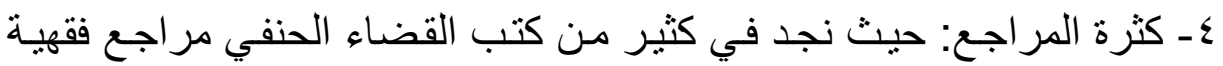

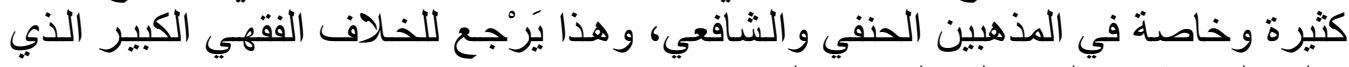
يوليه الحنفية في ألرد على المذهب الثنافعي.

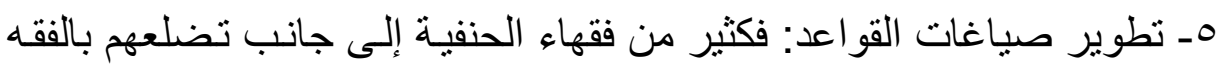

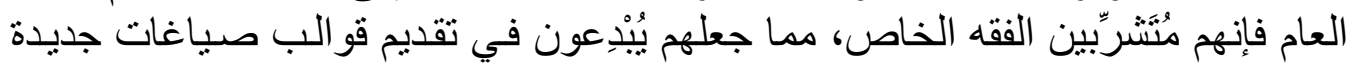
للقو اعد الفقهية و الأصولية المرتبطة بالقضاء.

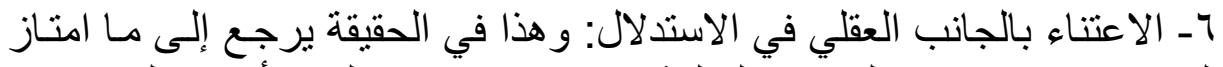

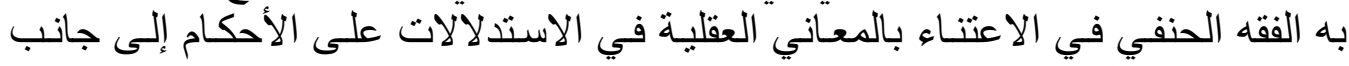
عنايته بالنص الثنر عي في الإثبات و النفي.

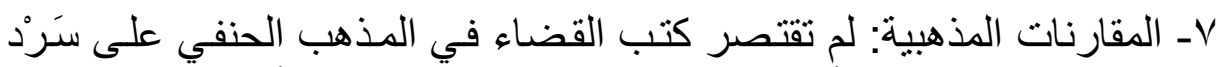

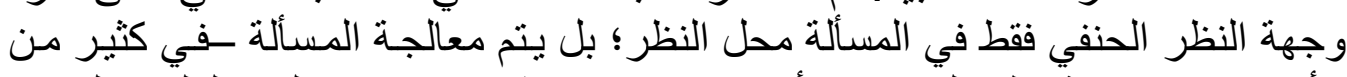

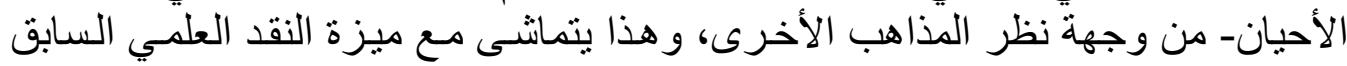

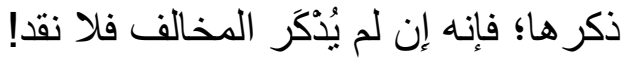

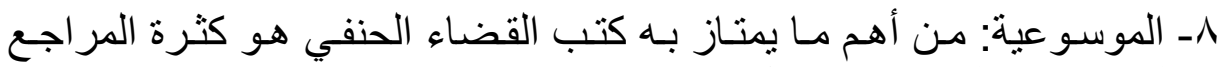
والمصادر التي يعتمد عليها في الدسائل التي يتم بحثنها.

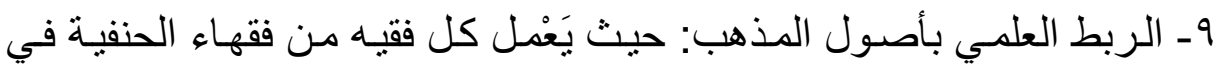
المسألة التي يقرر ها على الالتز ام بالمذهب فيما يتوصل إليه من قو اعد تطبيقية. 


\section{المبمث الثاني}

\section{منهج الإهام ابن مازة (ت: مبه هـ) في شرحه لكتاب}

\section{" أدب القاضي" ل الفصأف انموذجكا}

\section{المطلب الأول}

\section{نبذة مختمرة عن المؤلف(1)}

وفي هذا المطلب سيكون الحديث عن هذا الإمـام الجليـل ، ذو فئه المكانـة العاليـة

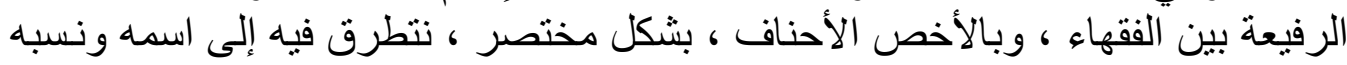

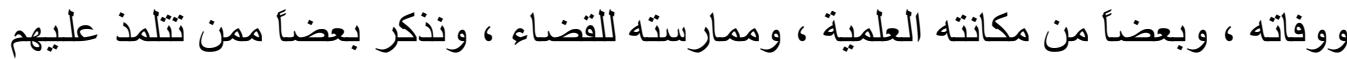

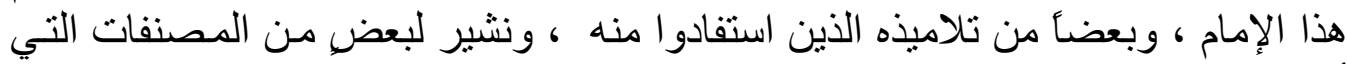
ألفها -ـرحمه الله تعالى - وووصلت إلينا.

\section{الفرع الأول: اسمه ونسبه ، ووفاته :}

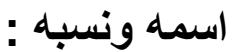

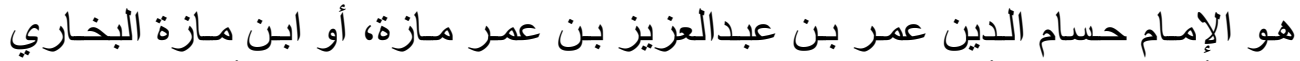

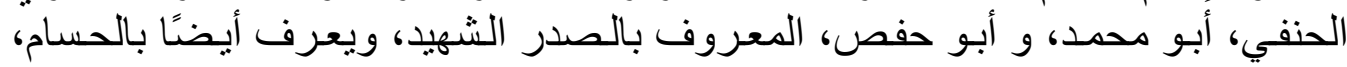
وبالحسام الثهيد.

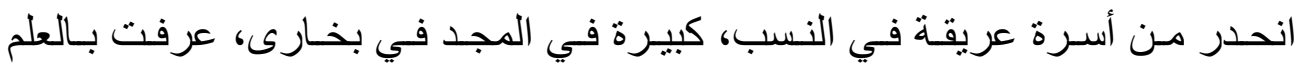

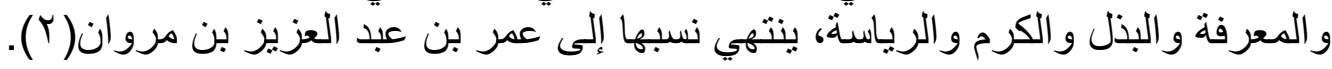

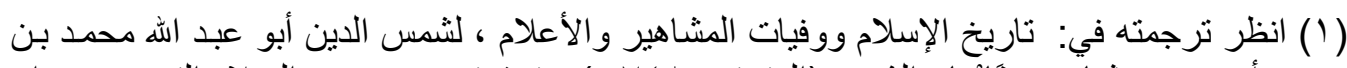

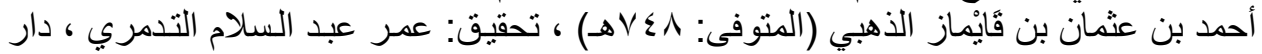

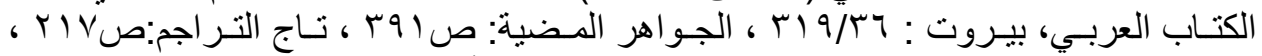

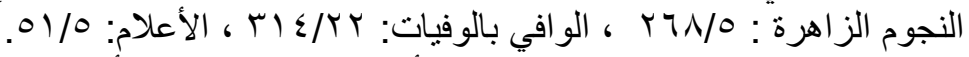

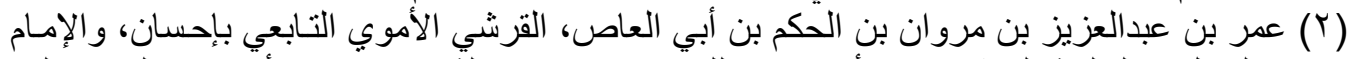

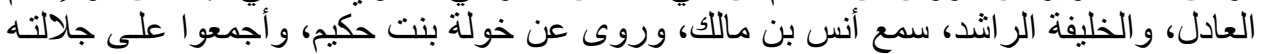

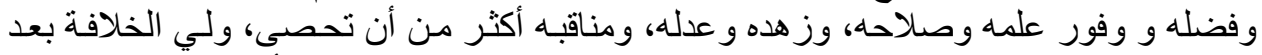

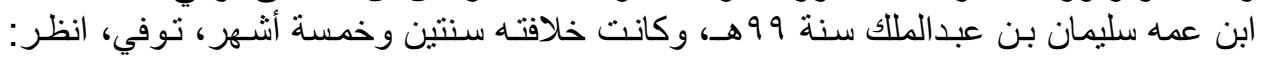

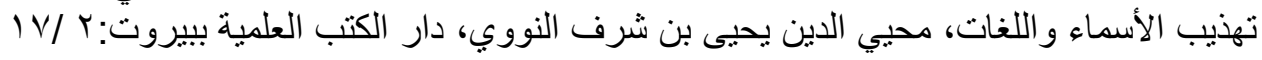




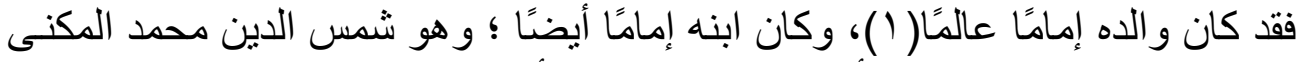

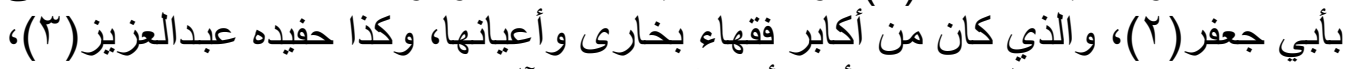

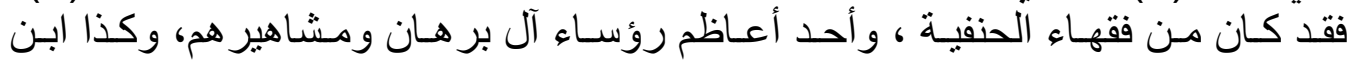

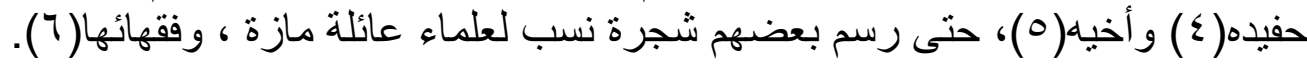
وقد ولد الصدر الحسام - رحمه الله - سنة (rی^یهـ) ، ونشأ في كنف و الده ور عايته. وقد حُكي أن أباه - رحمه الله - كان يخصص وقت الضدان الضحوة الكبرى لأبنائه ؛ يعلمهم

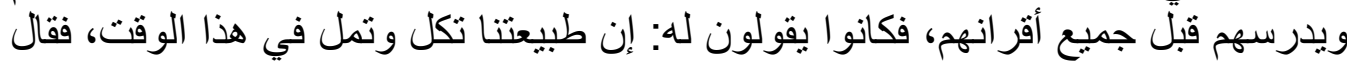

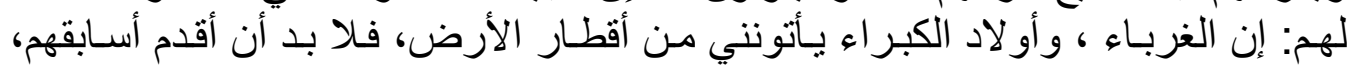

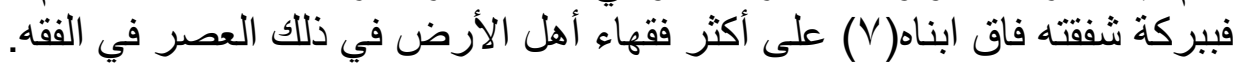

\section{وفاته [استشهاده]:}

قيل: إنه قتل صبرًا بسمرقند(^)، في صفر ، سنة ست وثلاثين وخمس مئة.

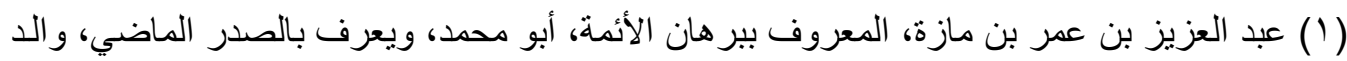

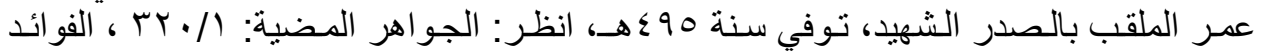

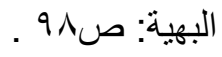

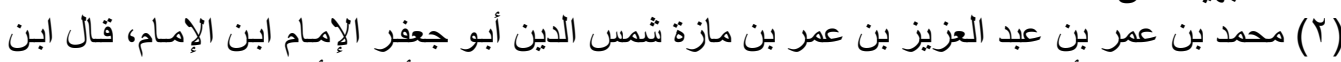

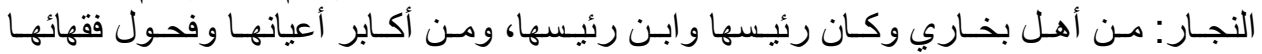

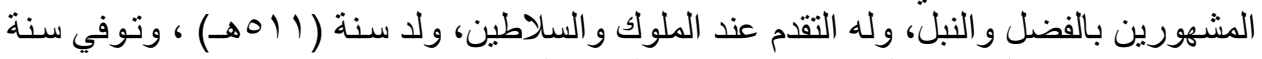

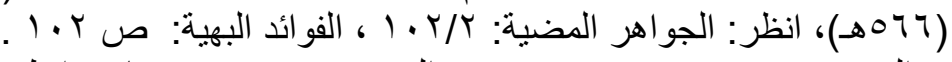

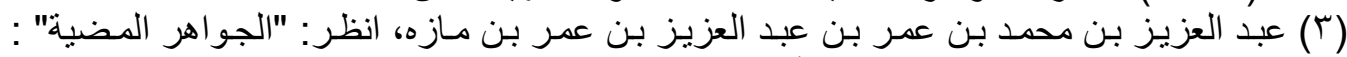

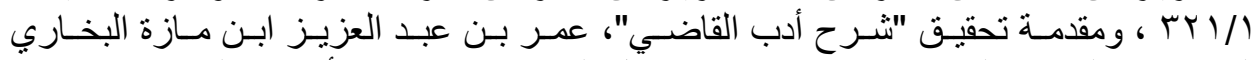

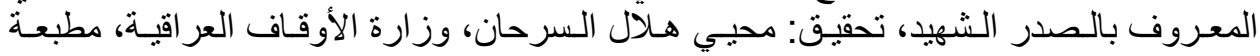

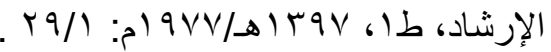

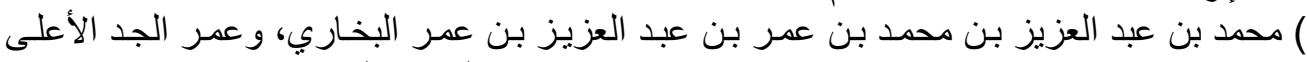

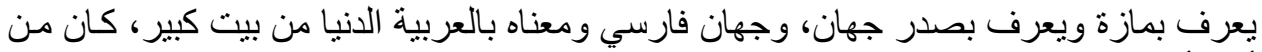

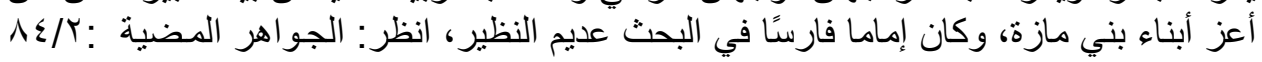

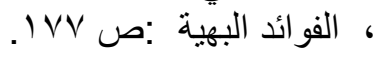

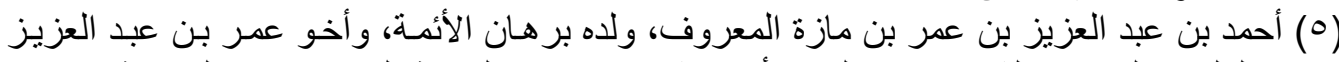

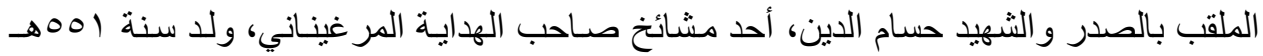

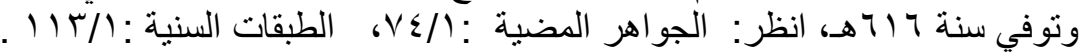

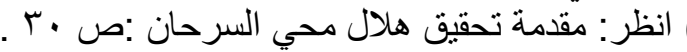

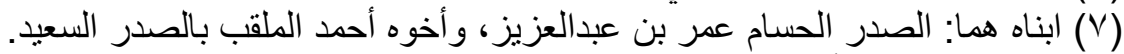

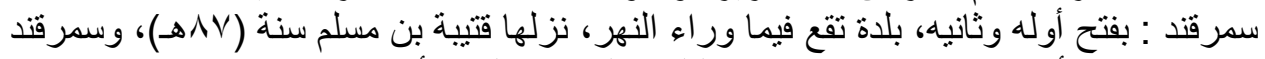

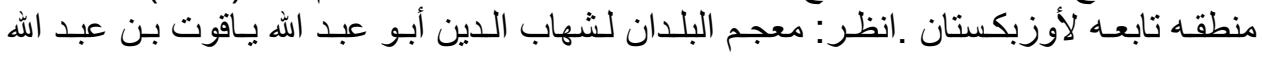

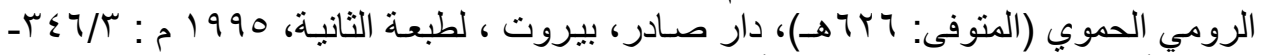

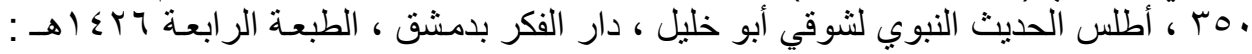




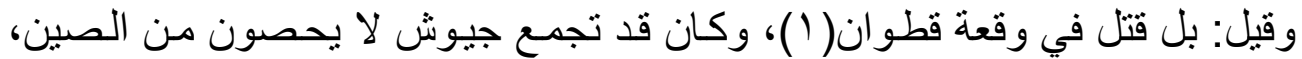

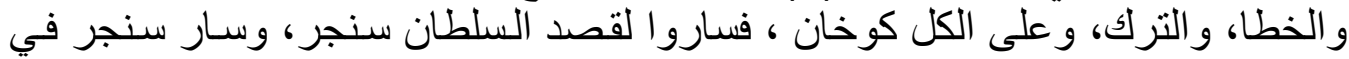

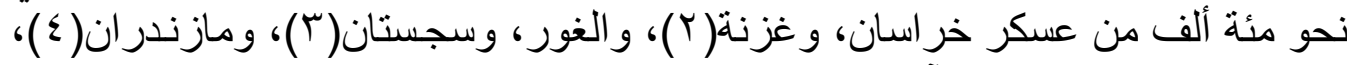
و عبر بهم نهر جيحون في آخر سنة خمس وثناثين وخمس مئة ، فالتقى الجيشان، فكانا

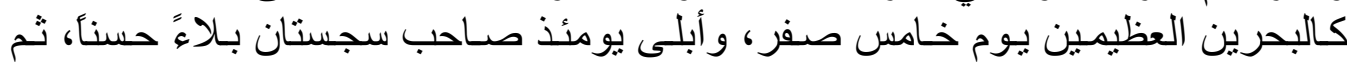

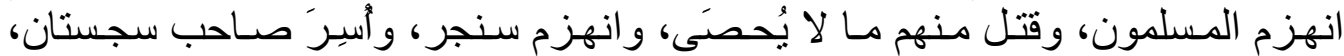

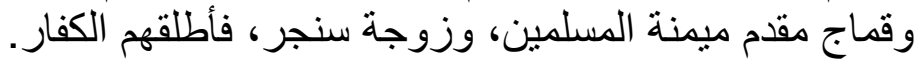

قال ابن الأثير(0): وممَّن قَتْلَ: الحسام عمر بن مازة الحنفي، المشهور( (؟). قال: ولم يكن في الإسلام وقعة أعظم من هذه، ولا أكثر ممن قتل فيها بخر اسان. واستقرت دولة الخطا، والترك الكفار بما ور اء النهر، وبقي كوخـان إلى رجب سنة

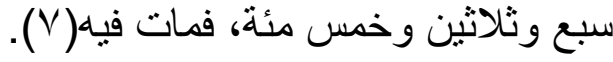

\section{الفرع الثاني: مكانته العمية وهل مارس القضاء.}

اجتهد في التحصيل، حتى بر ع في مذهب الإمـام أبي حنيفة - رحمـه الله -، و أخذ فئ يرتفع فضله شينًا فنشينًا، ففاق الفضلاء في في حياة أبيه بخرسان.

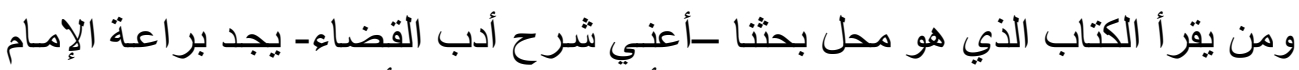

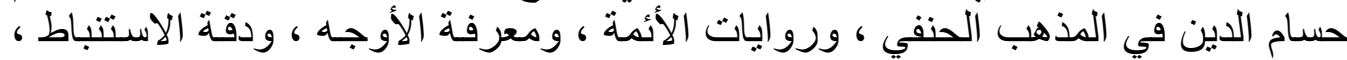

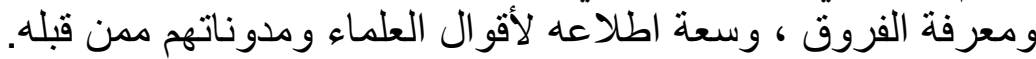

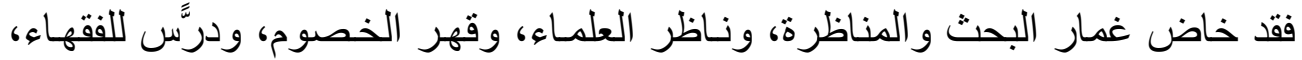

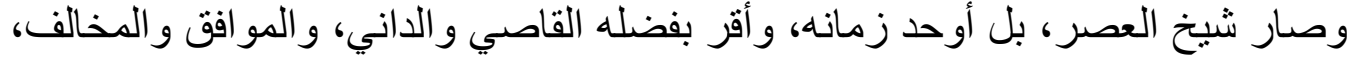

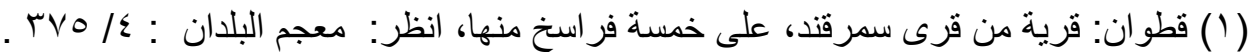

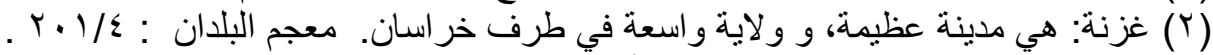

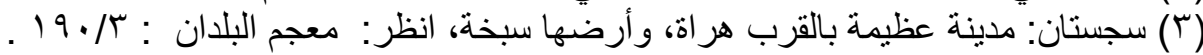
( ) مازندران: اسم لو لاية طبرستان، و هي بلدان و اسعة كثيرة يشملها هذا الاسم، انظر: : معجم البلدان . 1 .

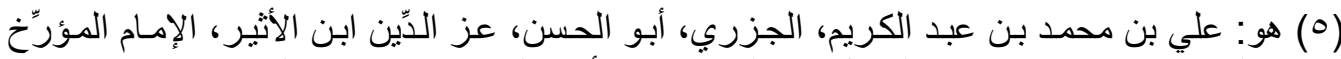

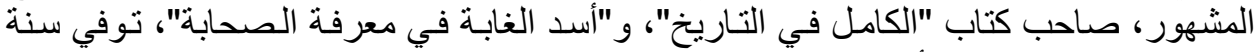

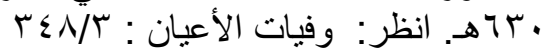

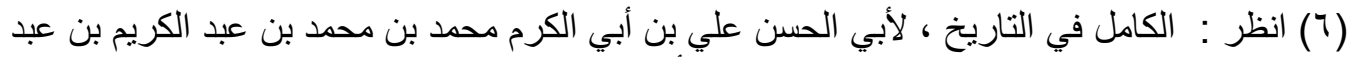

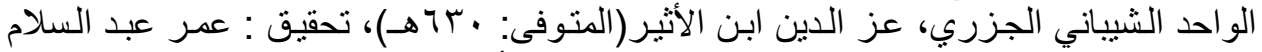

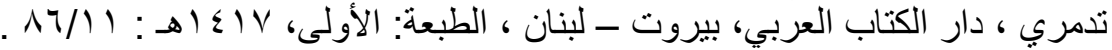


حتى وصـل صبيته إلى مـا ور اء النهر، وصـار السلطان ومن دونـهـ يعظمونـه، ويتلقون

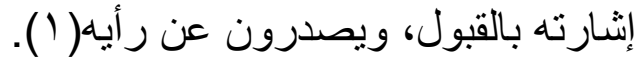

قال القرشي :" وذكره صاحب الهداية فى معجم شيوخه وقال: تلققتُ من فلق فيه من فن فئ

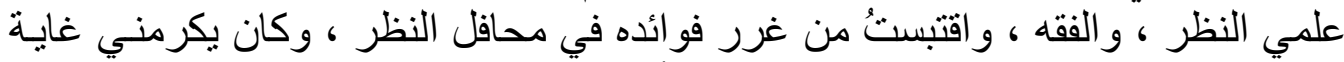

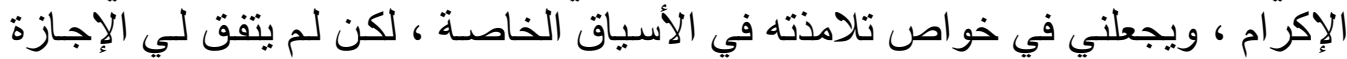

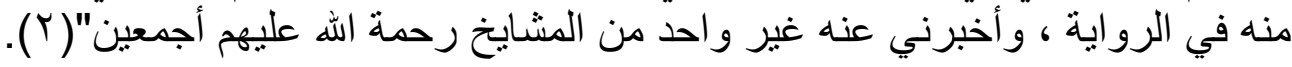
ولايته القضاء : بعد التتبع لسيرته لم أجد من يذكر أنه ولي القضاء.

\section{الفرع الثالث: أهم شيوخه وتلاميذه ومصنفاته.}

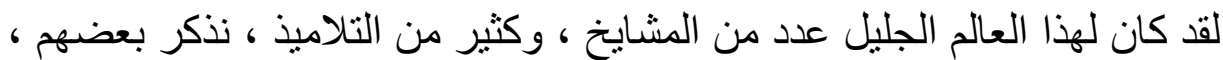
ونشير إلى بعض النتاج العلمي لهذا العَّم بشيء من المن الايجاز :

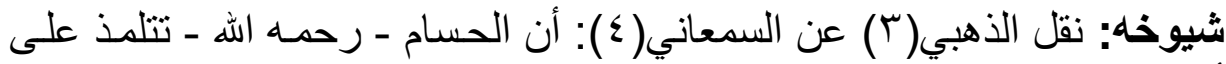

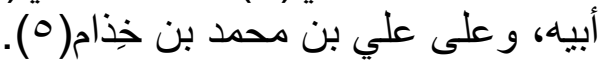
وحدث عن جماعة من البغداديين، منهم:

( () انظر تحقيق محي هلال السرحان لشرح أدب القاضـي، فقد ذكر بعض التفاصيل في سيرة الإمـام

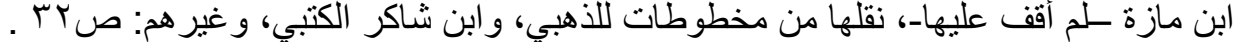

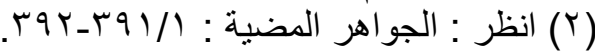

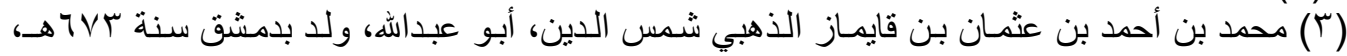

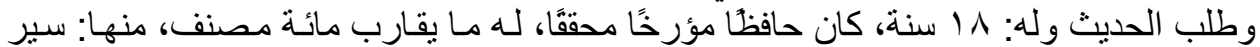

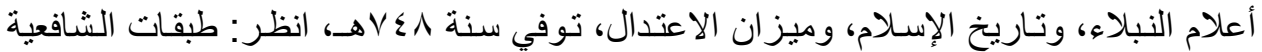

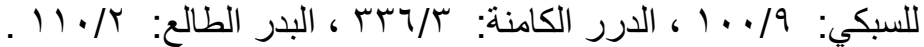

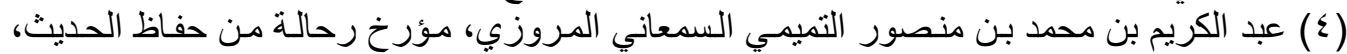

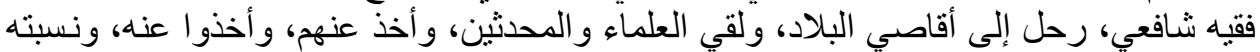

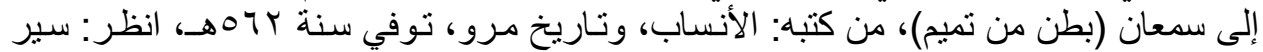

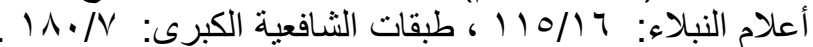

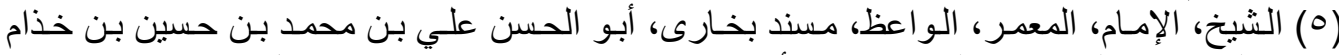

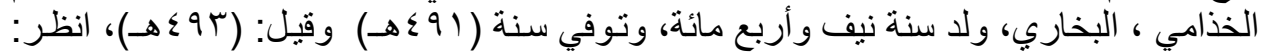

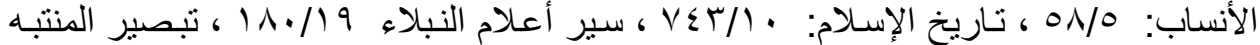

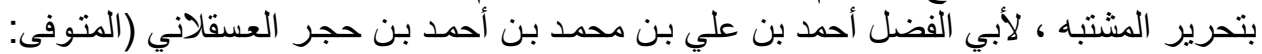

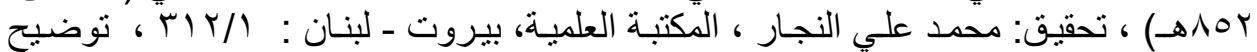

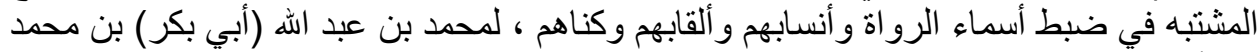

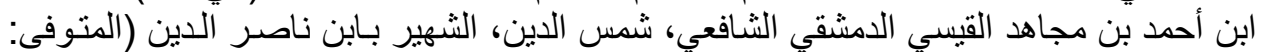

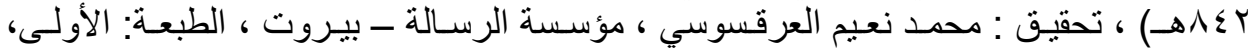




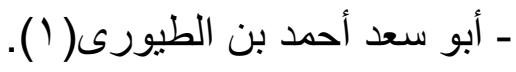

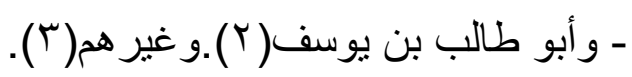

تلاميذه:اشتهر علم الحسام - رحمـه الله - في زمانها، وقصده القاصي و والداني،

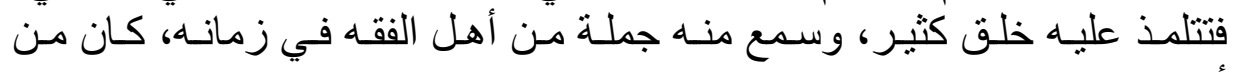
أبرز هم: 1. ابنه شمس الدين أبو جعفر محمد(؟). r. أ. و أخوه تاج الدين أحمد الملقب بالصدر السعيد(0).

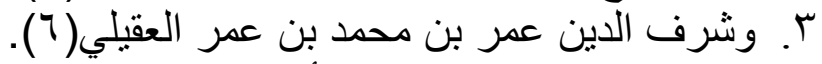

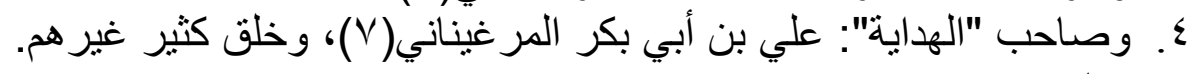

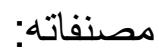

( ( أحمد بن عبد الجبار بن أحمد بن القاسم الصيرفي، ابن الطيوري البغدادي، الدقرئ، الدلال في

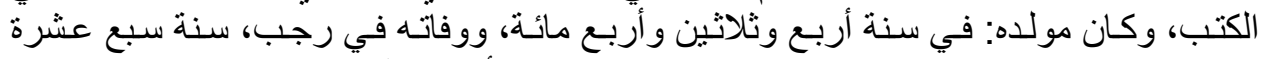

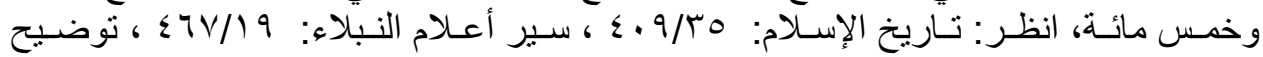

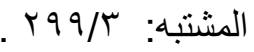

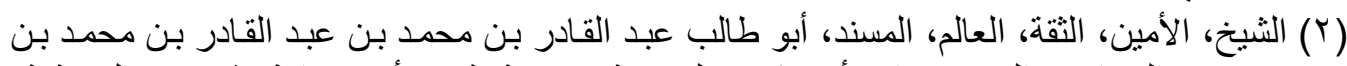

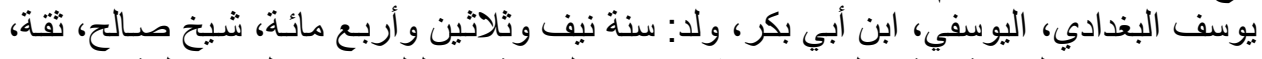

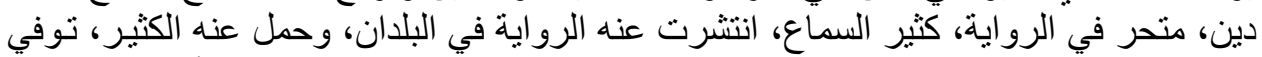

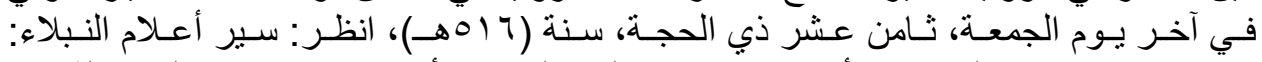

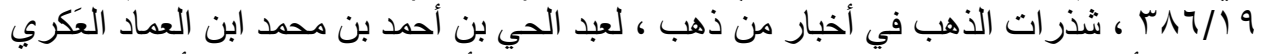

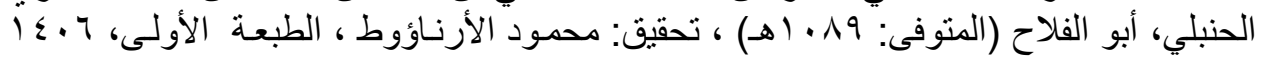

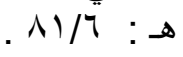

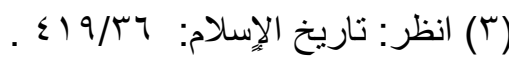

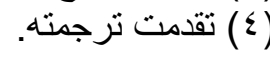
( ) (0قدمت ترجمثن.

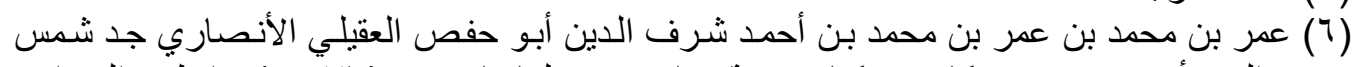

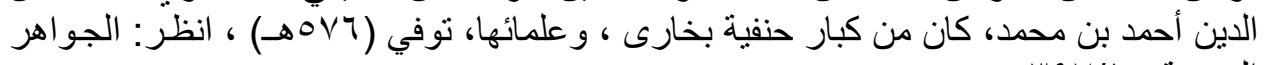

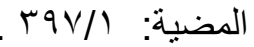
(Y) علي بن أبي بكر بن عبد الجليل الفرغاني الدرغيناني، أبو الحسن بر هان الدين: من أكابر فقهاء

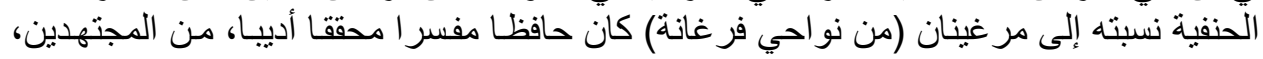

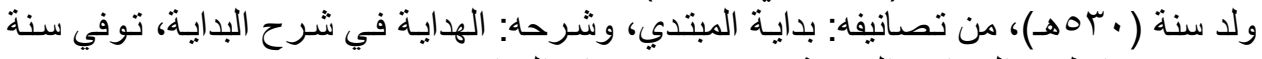

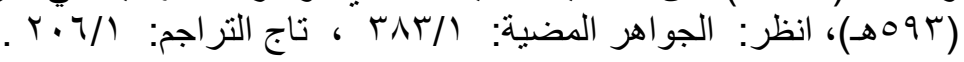




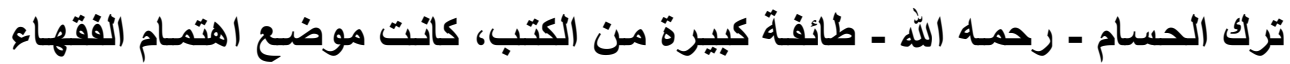

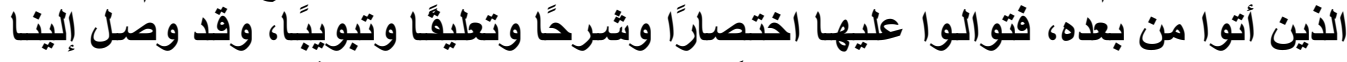

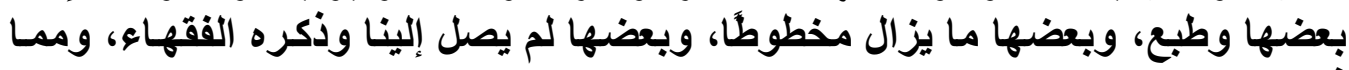

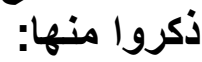

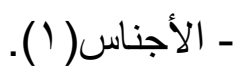

- (بتاب أصول الفقه(ب).

ـ الجامع الصغير في الفروع(ب). - شرح أدب القاضي لأبي يوسف(ع).

ـ شرح أدب القاضي للخصاف. وهو الذي شرح فيه رسالة القضاء، موضوع بحثنا. - شرح الجامع الصغير. - عمدة المفتي و المستفتي(0). - كتاب الوقف و الابتداء(7). و غير ها من الكتب القيمة والنفيسة

\section{1المطلب الثناني}

\section{أهمبة الكتناب العلمبة}

\section{يمكنا القول بأن الأهمية تتبع مما يلي :}

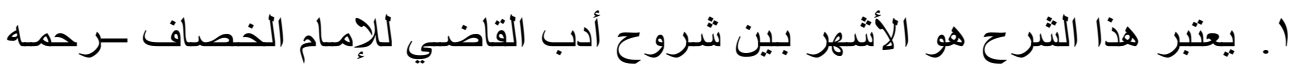

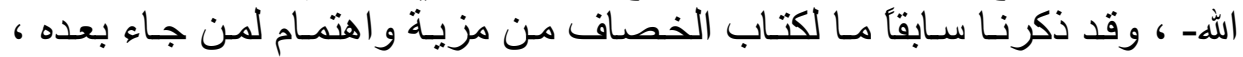

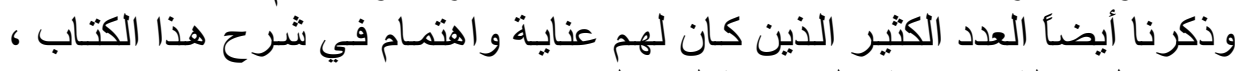

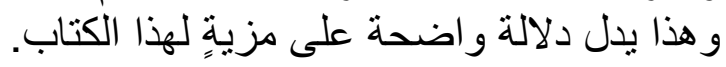

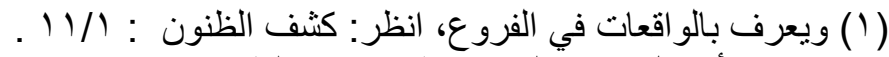

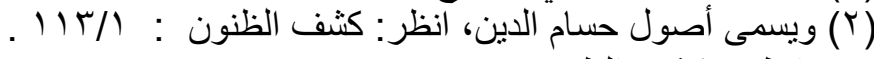

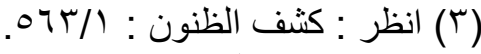

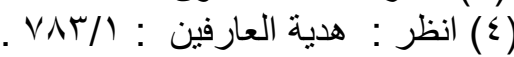

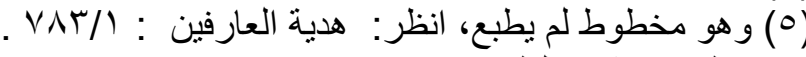


Y. هذا الكتاب يعد مصدر آ مهمأ للأحناف في تقرير مذهب أبي حنيفة ، وصـاحبيه ،

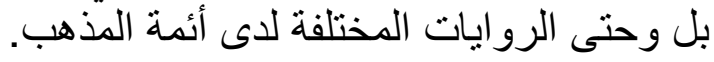

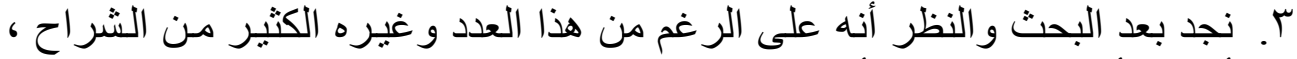

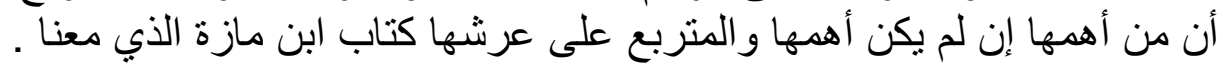

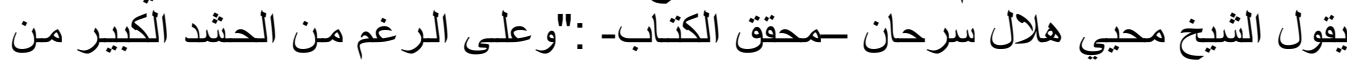

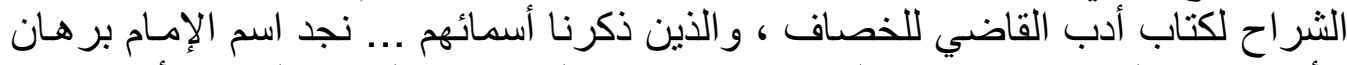

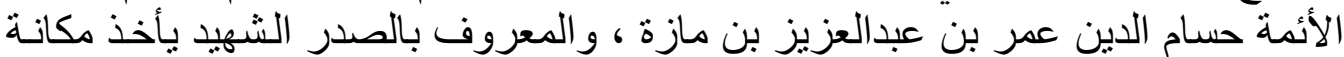

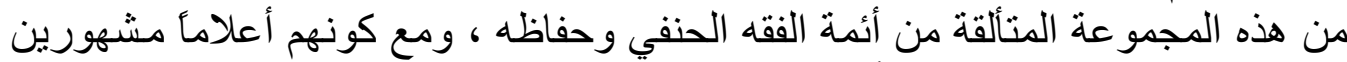

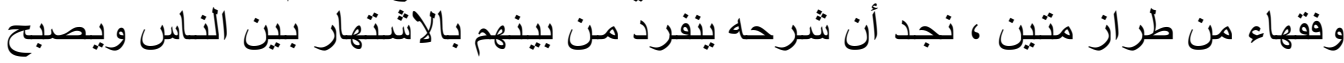

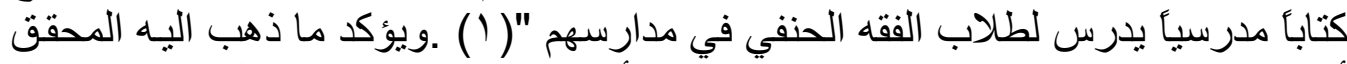

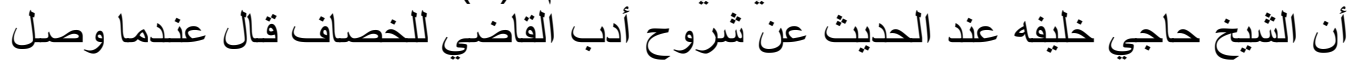

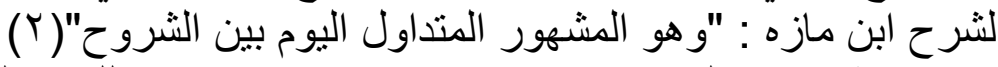

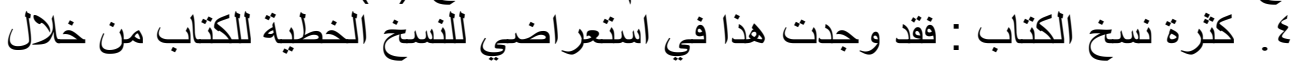

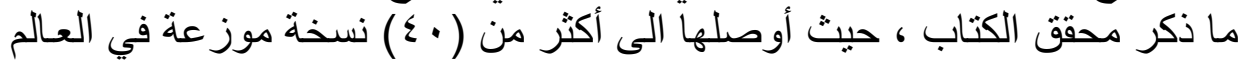

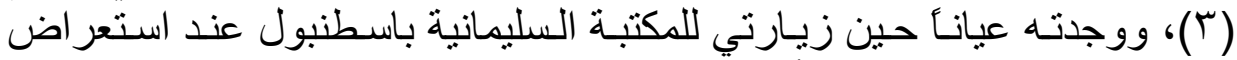

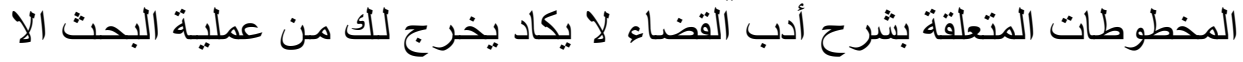

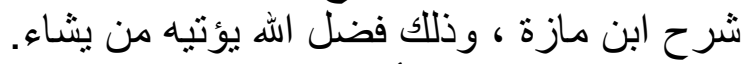
๑. ومما يزيد هذا الكتاب أهمية ما يلاحظه القارئ فئ في كتب لأب الأحناف من كثرة النقول

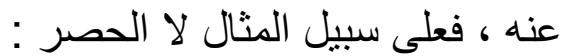

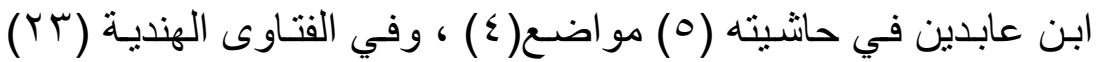

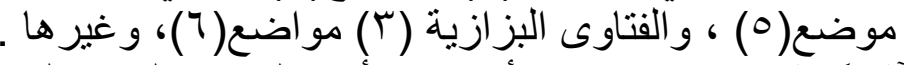

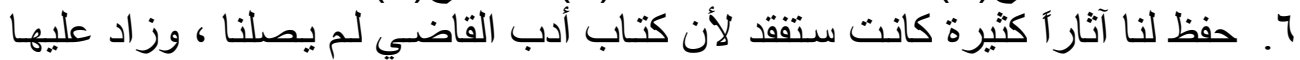
تلك الفو ائد المستنبطة من عالم متفن كانت في المذهب.

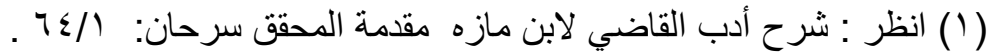

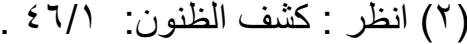

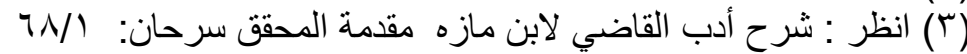

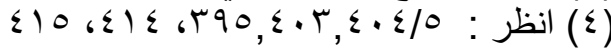

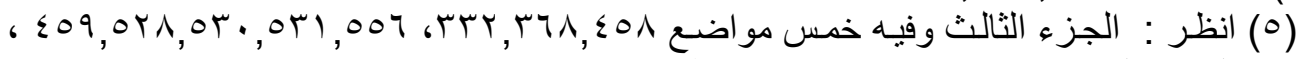

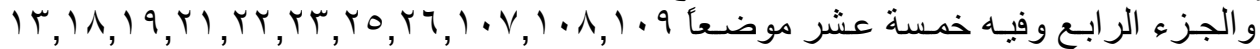

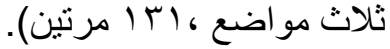

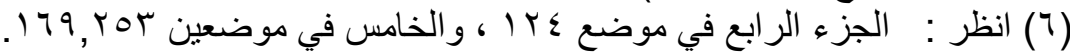




\section{المطلب الثالث}

\section{منـهج المؤلف في الكتئاب}

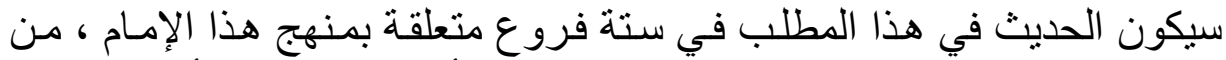

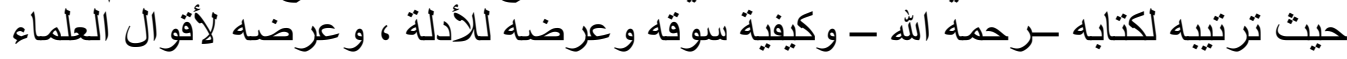

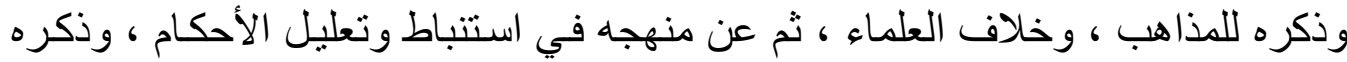

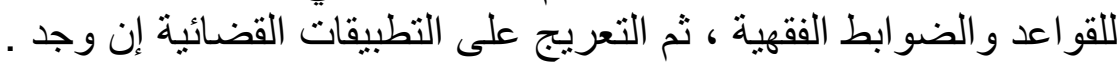

\section{الفرع الأول: منهجه في ترتيب الكتاب.}

لقد كان منهج المؤلف في هذا الشرح مسلكاً وسطاً يمكن ايجـاز ترتيبه للكتاب على النحو الآتي :

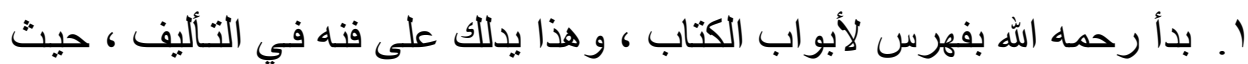

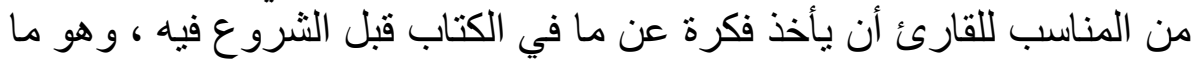

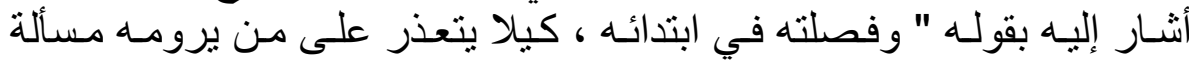

r. دمج بعض الأبو اب في بعض فجعلها مائة و عشرين بابـأ لإندر اج بعضها في بعض كما يقول هو في مقدمة الشرح.

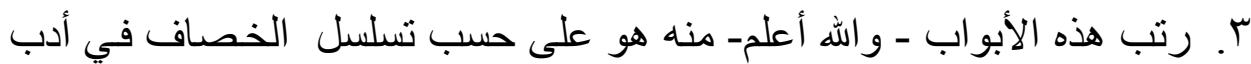

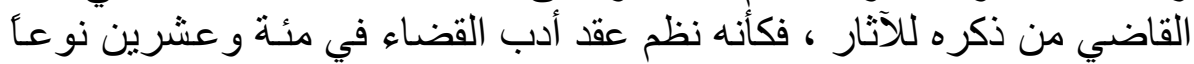

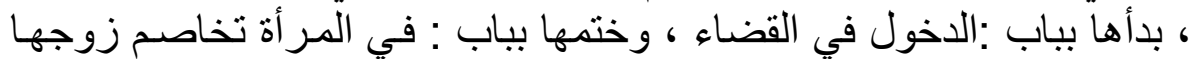
في ولاها.

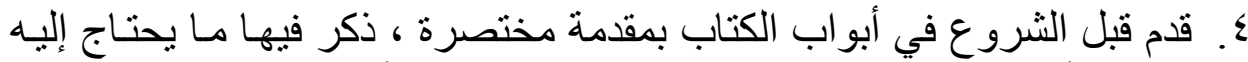

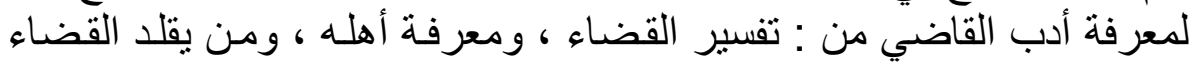

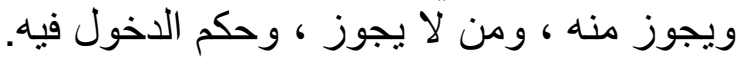

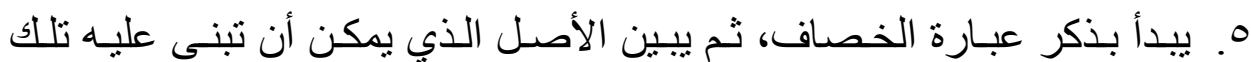

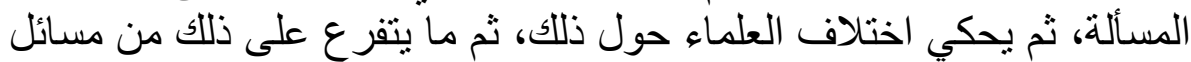

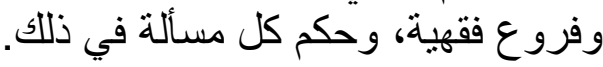

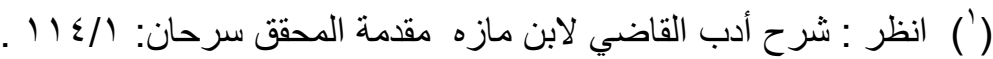


T. عند اير اد الخصاف بعض التساؤلات ويجيب عليها ، يذكر ها الثارح ، ويعلق . والق

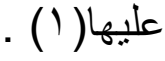

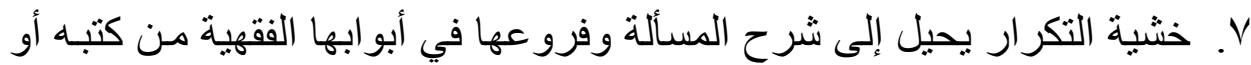
غيره، ويبين ما يقع على المتن من استدر اكات.

العنابة به :

لقد حقق هذا الثرح من قبل محيي هـلال السرحان " معاصـر " بتكليف مـن لجنة إحياء

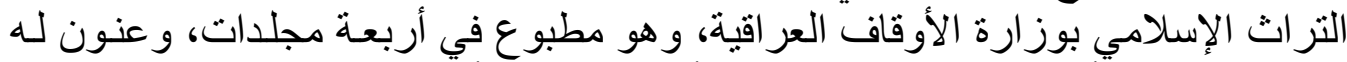

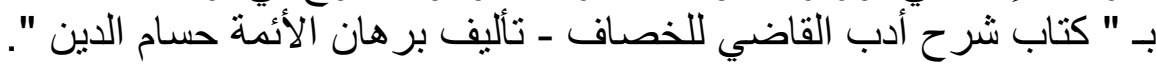

كمـا أن الكتاب مطبوع في مجلد واحد بتحقيق أبي الوفـاء الأفغاني، و أبي بكر محمد الهاشمي.

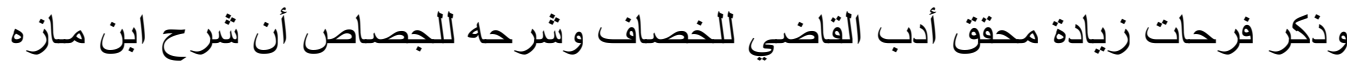

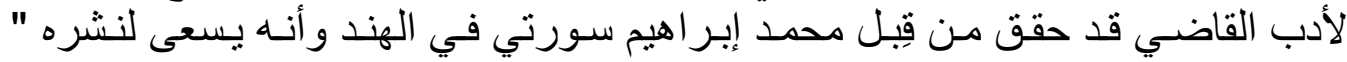

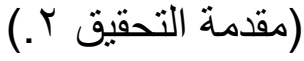

\section{الفرع الثاني: منهجه في عرض الأدلة.}

يمكن القول بأن منهج الإمام حسام الدين في ذكره و عرضه للأدلة على النحو التالي:

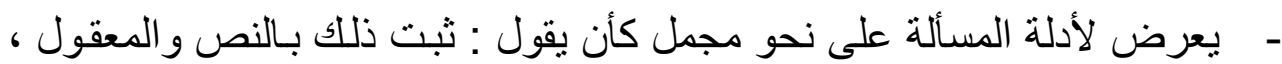

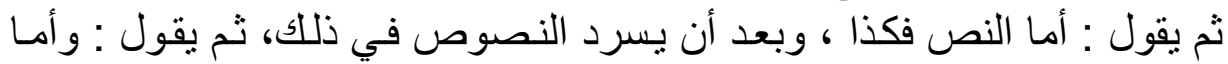
المعقول فكذا ، و هذا ترتيب بديع ، وكان يذكر الحكم مشفو عأ بالداليل من الكتاب،

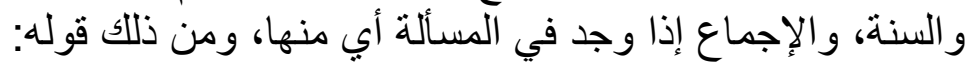

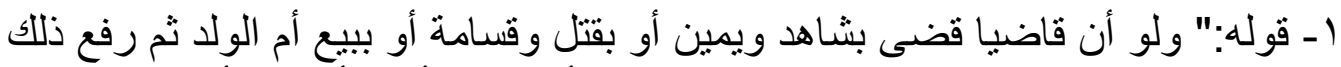

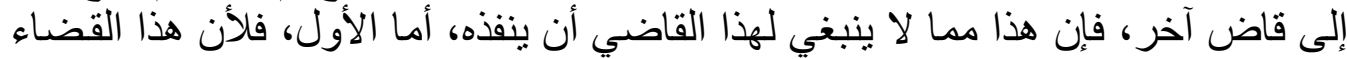

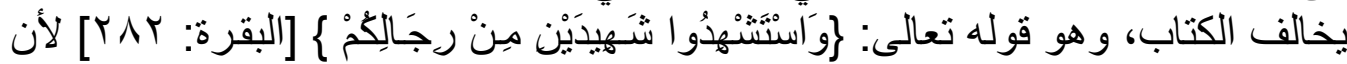

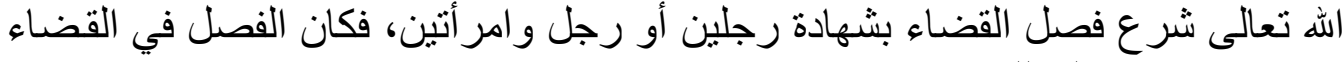

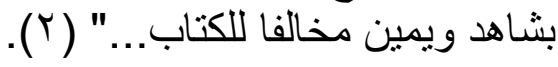




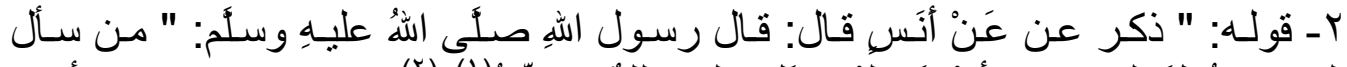

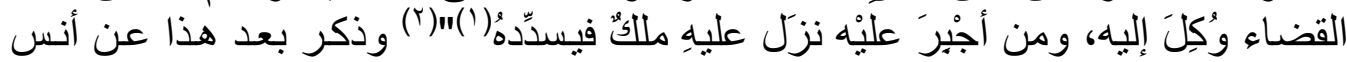

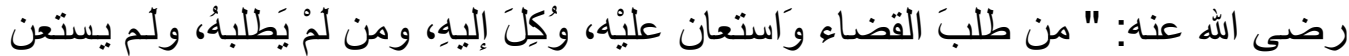

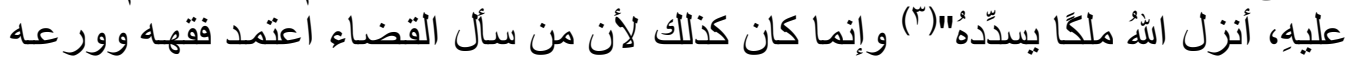

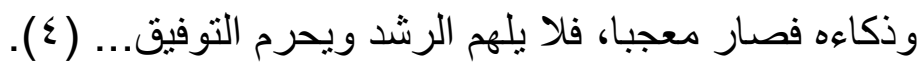
- قد يصحح بعض روايات الحديث على بعض(0) . - كان غالبا ما يذكر وجه الدلالة من الاليل ومحل الثاهد منه، ومن ذللك:

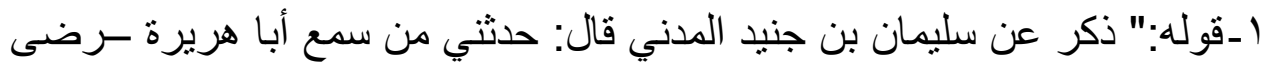

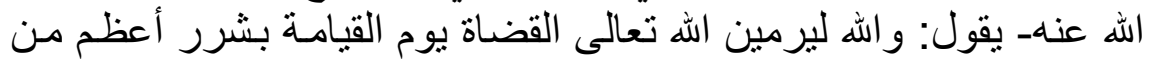

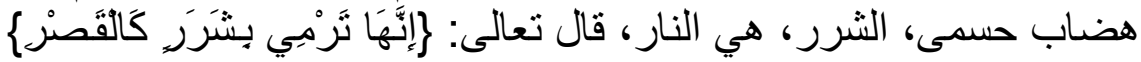

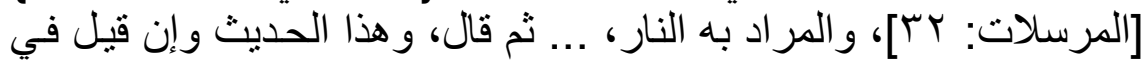

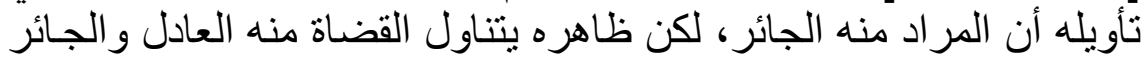

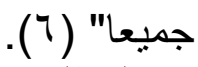

ץ-قوله في المطلقة تستحق النفقة في العدة:" ذكر عن إبر اهيم النخعي نفقة المطلقة

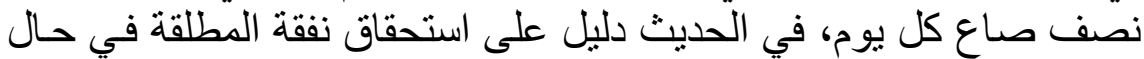

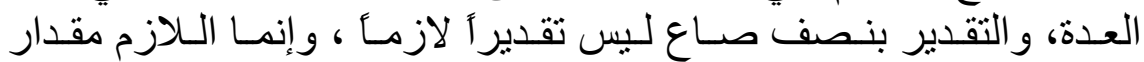

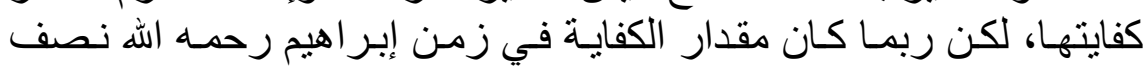

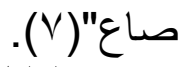

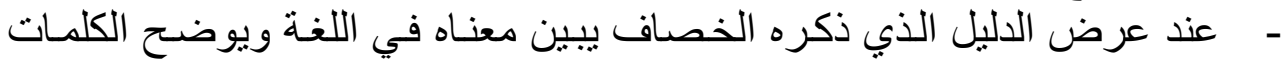

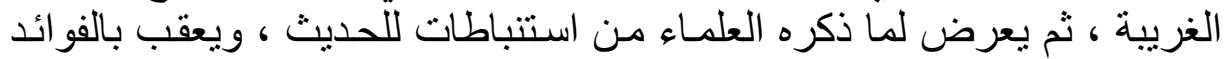

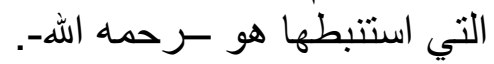

- قد يعرض لدليلين ظاهر هما التعارض ، فيعد للتوفيق بينهما (^).

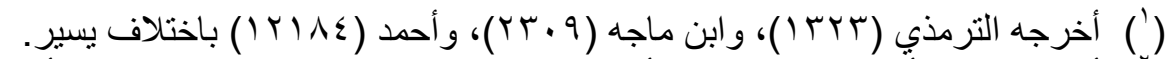

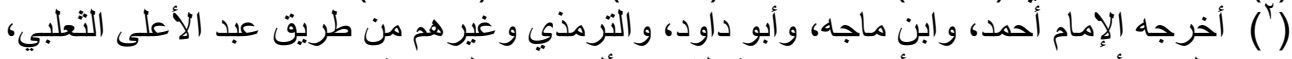

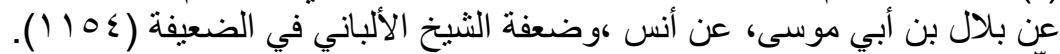

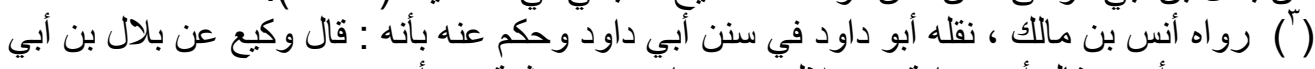

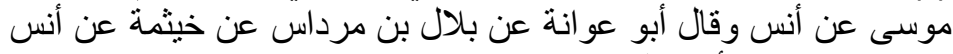

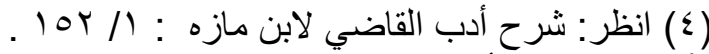

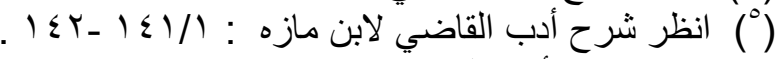

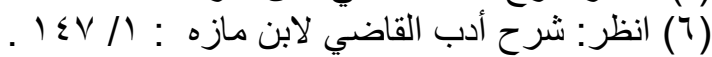

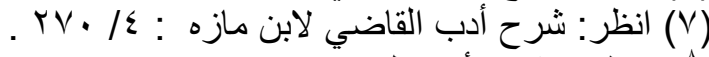

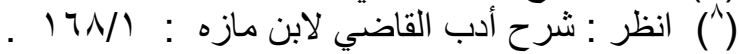


- قد يستدل بالقياس ، كما قاس وجوب تبين القاضي الحق كما يتبين الليل والنهار

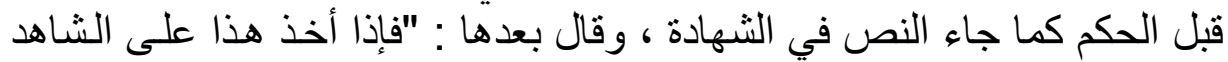

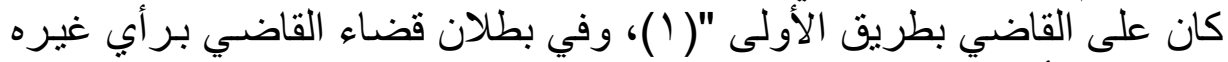

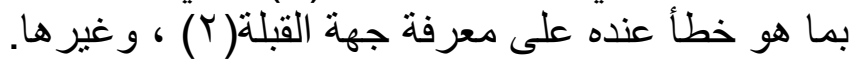

- يرى نسخ السنة بالكتاب(r) .و هذا مذهب الأحناف ، و الخلاف فيها معروف(ع ).

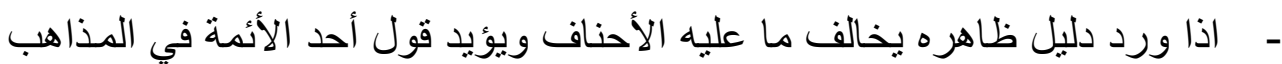

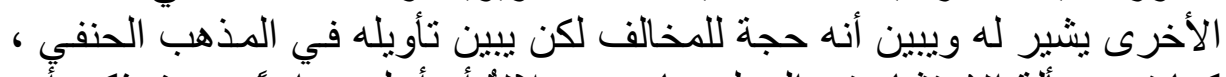

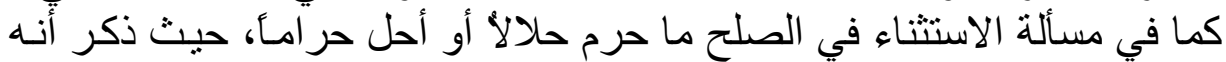

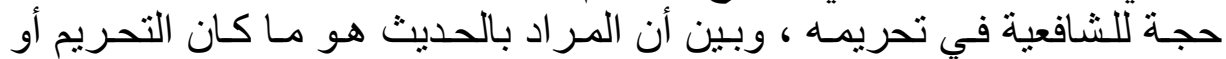

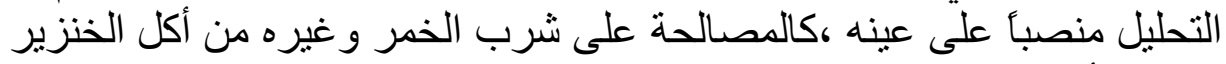

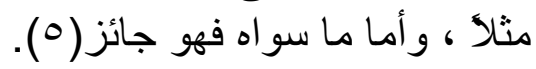

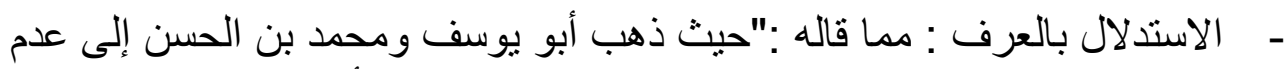

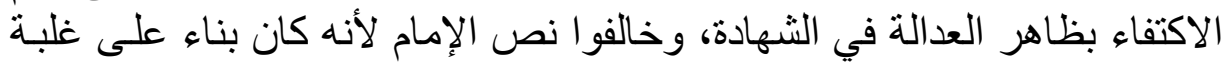

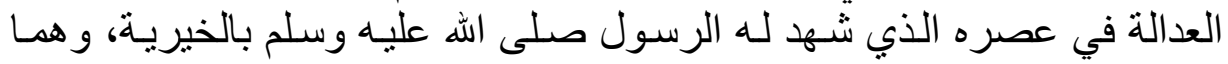

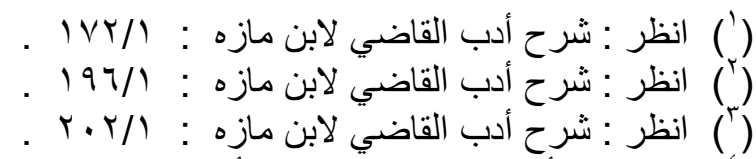

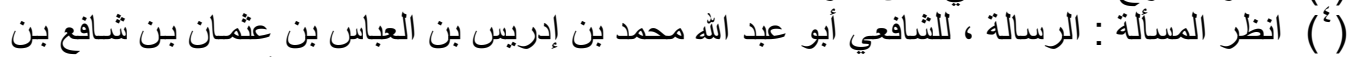

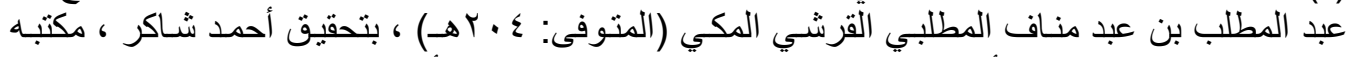

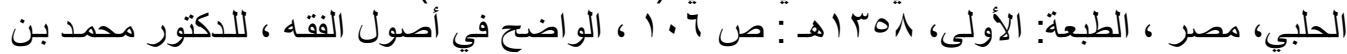

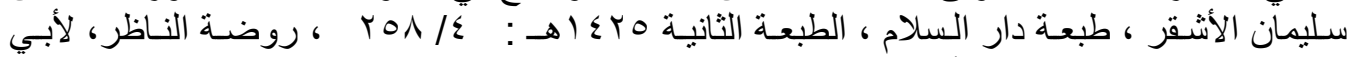

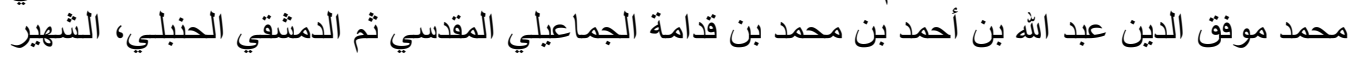

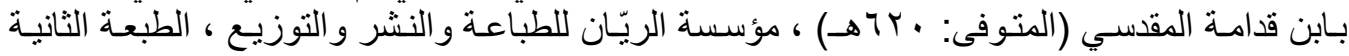

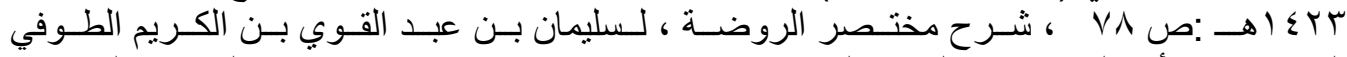

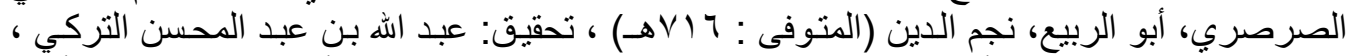

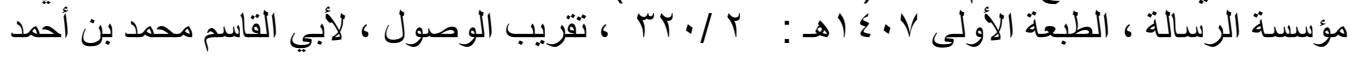

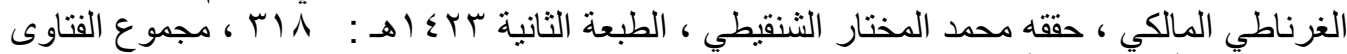

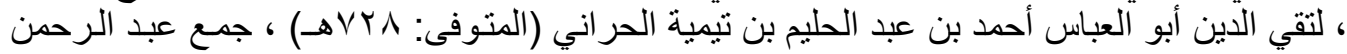

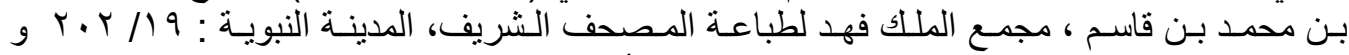

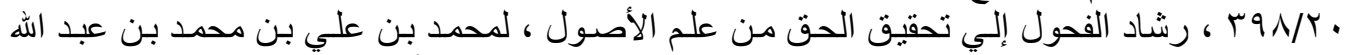

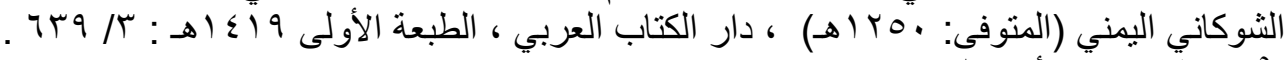

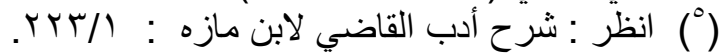


أدرك الزمن الذي فنشا فيه الكذب، ونصوا على أن هذا اختلاف عصر و أوان لا

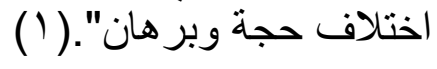

الفرع الثالث: منهجه في عرض أقوال العلماء والمذاهب وذكر الخلاف الفقهي. يمكن القول بأن منهج الإمام حسام الدين في ذكره وعرضه لأقوال العلماء والمذاهب ،وذكر الخلاف الفقهي على الإنح النحو التالي:

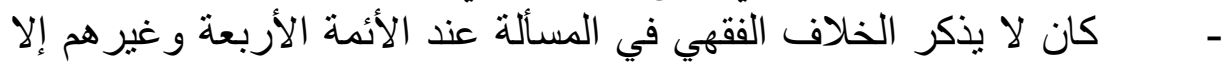

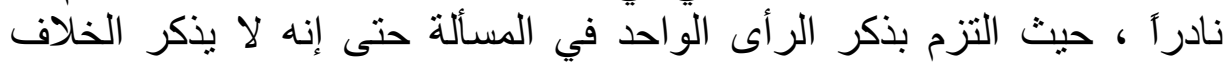
داخل المذهب ، ومن ذلك: قوله في عزل القاضي لريبة ولغير ريبة:" فإذا أراد القاضي أن يقبض ديض ديوان

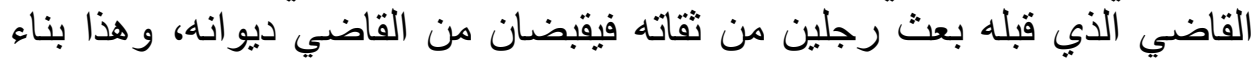

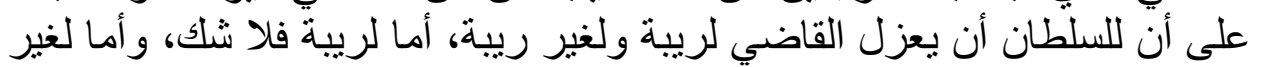

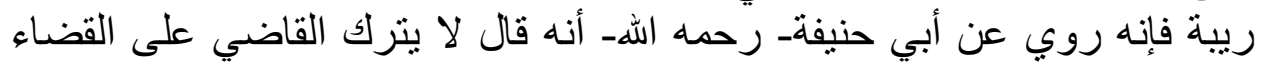

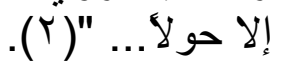

- كان أحيانا ما يشير إلى قول الإمام الثنافعي في المسألة مقارنا بينه وبين قول المذهب، ومن ذلك: الكيان مان

قوله:" وقضاء الفاسق ينفذ، وقضاء المحدود في قذف بعد التهن التوبة لا ينفذ، و عند الشافعي- رحمه الله - الأمر على العكس"(r).

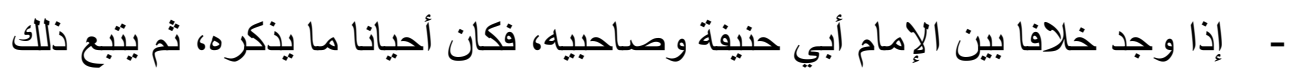

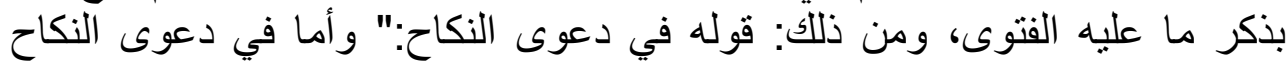

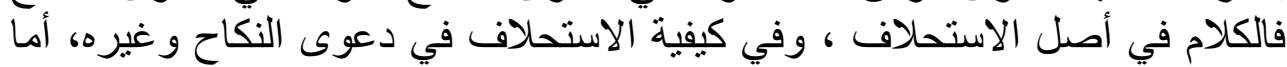

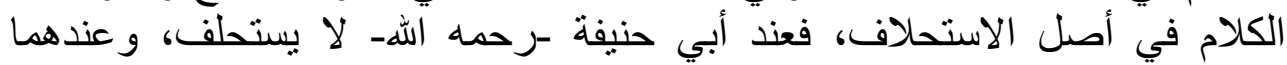

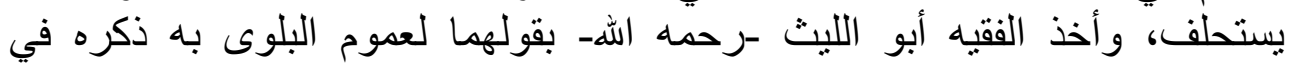

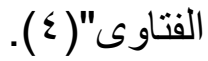

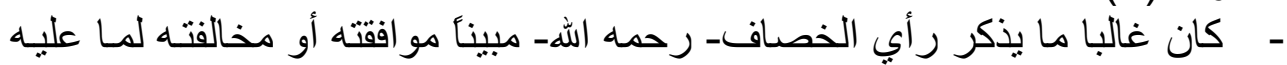

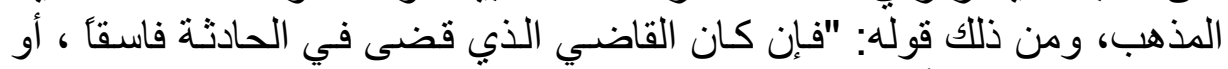

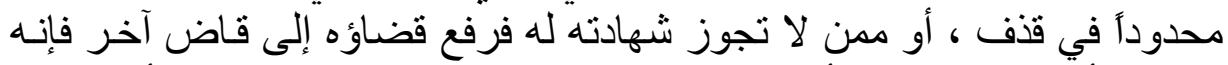

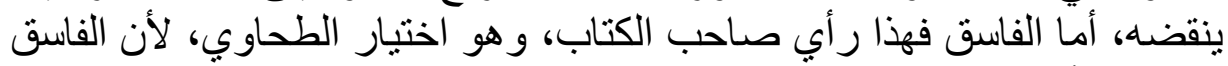

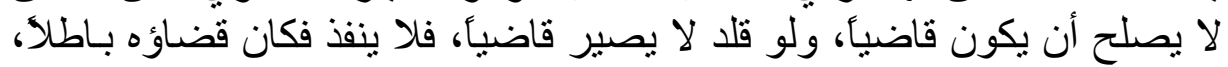

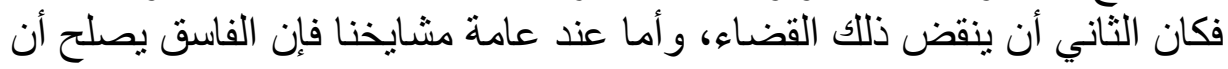

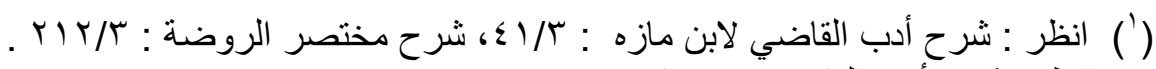

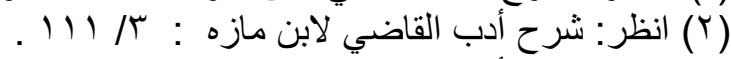

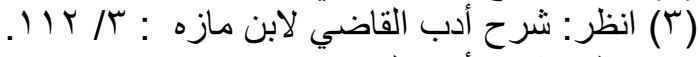

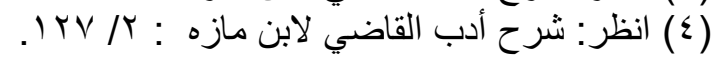

$$
\begin{aligned}
& -109 \mathrm{~V}=
\end{aligned}
$$




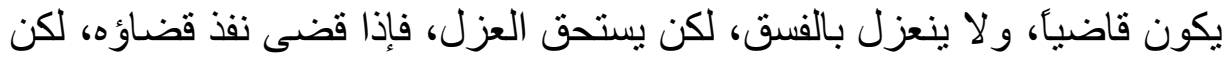

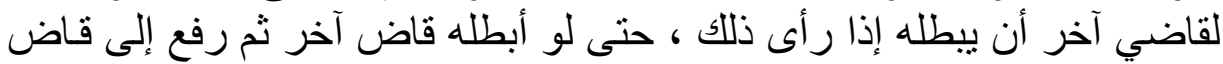

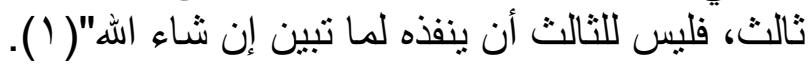

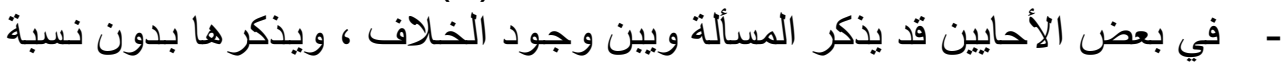

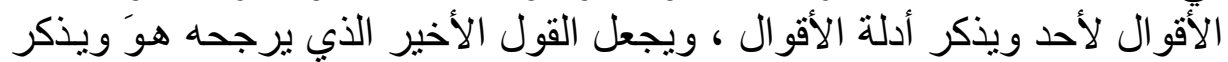

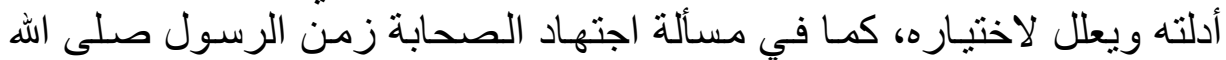

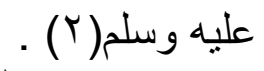

قد يذكر خلاف المذاهب في المسألة وهو قليل جداً : فيذكر أقو ال الأئمسة الثلاتـة

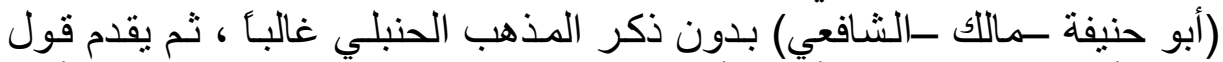

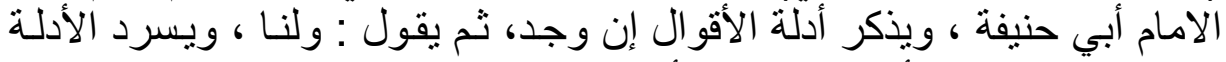

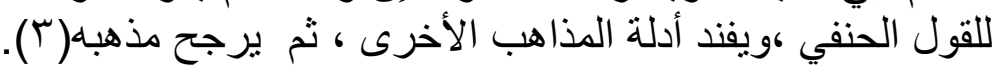

- ق قد لا يذكر الخصاف اختلافأ في المسألة فيبن الشار ح ذلك، و أن في المسألة خلافأ

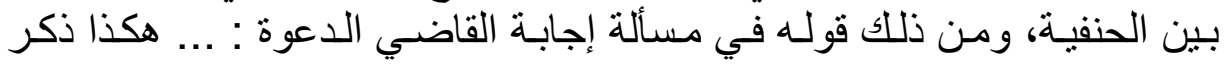

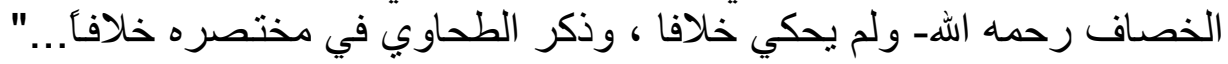

\section{كان أحيانـا يذكر الروايـات في المذهب، مبينـاً الصحيح منهـا، ومـا هو ظـاهر

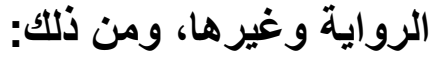

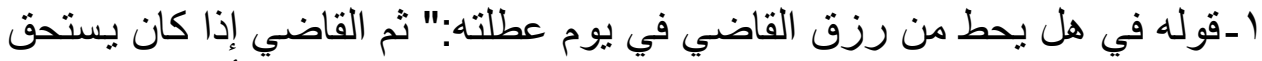

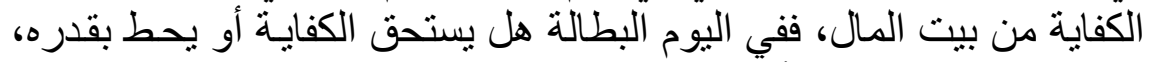

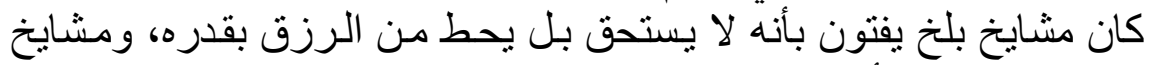

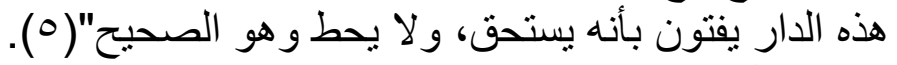

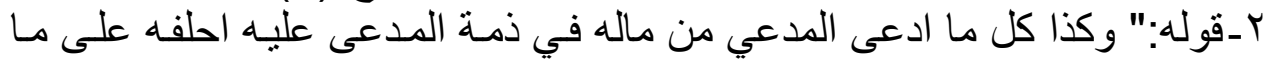

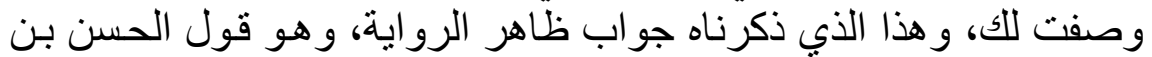

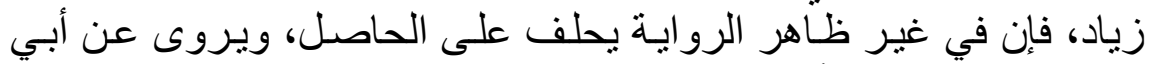

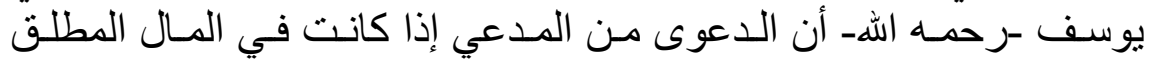

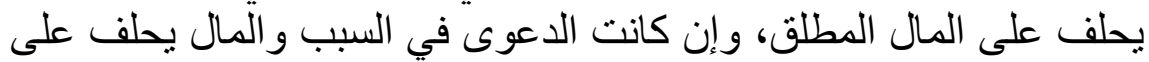

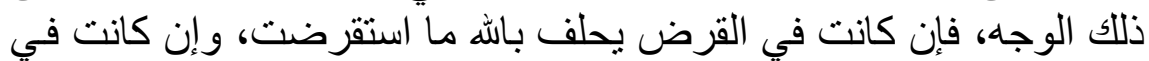

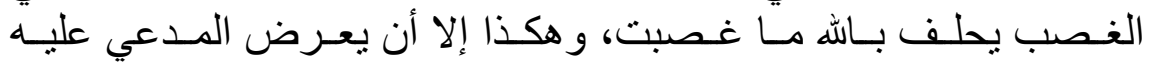

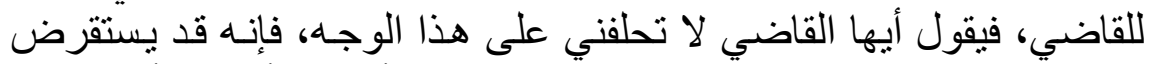

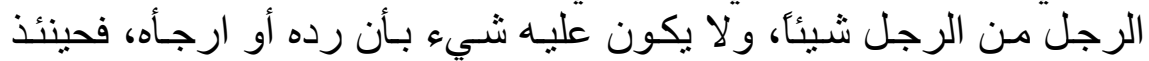

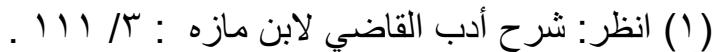

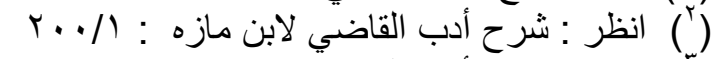

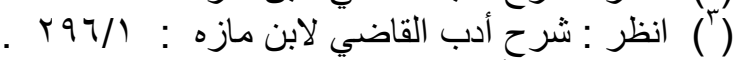

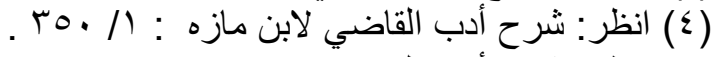

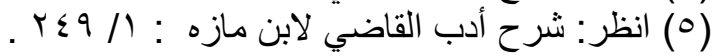


يستحلفه على الحاصل، قال مشايخنا: الأول: أصح لأنه أحوط "( (').

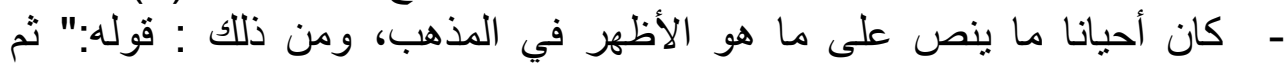

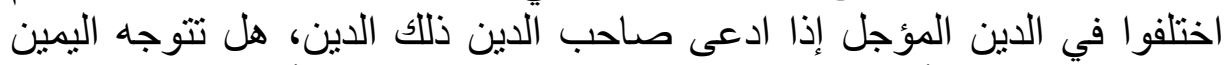

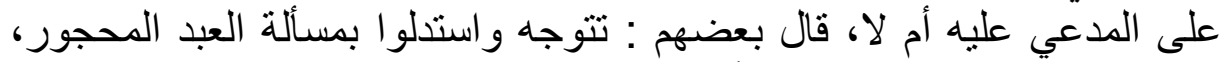

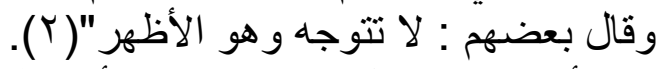

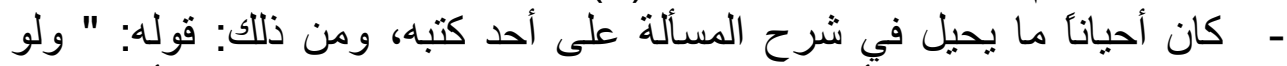

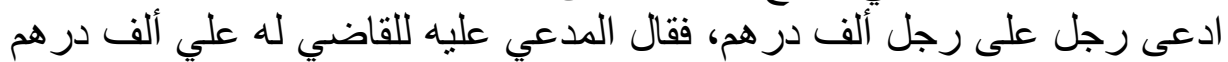

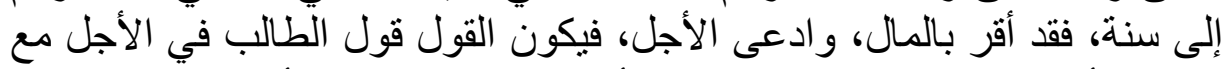

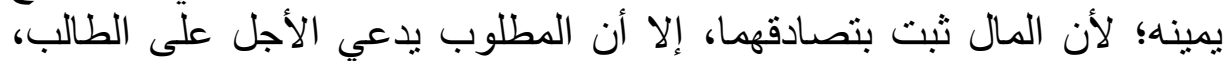

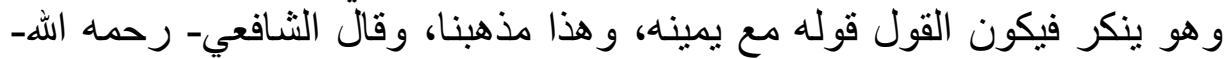

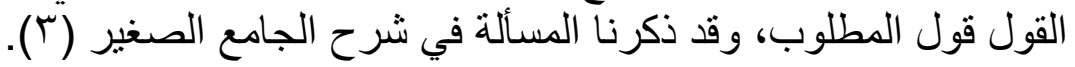

\section{الفرع الرابع: منهجه في الاستنباط وتعليل الأحكام.}

يمكن القول بأن منهج الإمسام حسام الدين في استتباطه وتعليله للأحكام على النحو التالي: - ne

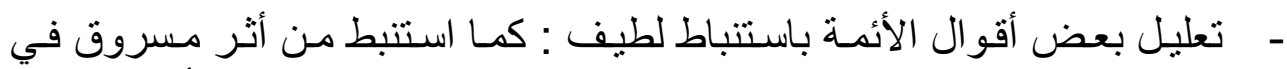

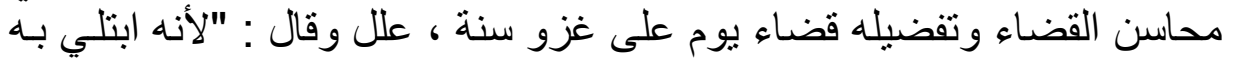

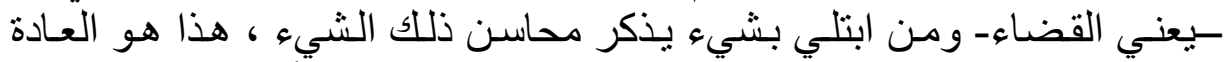

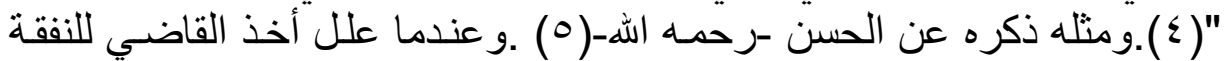

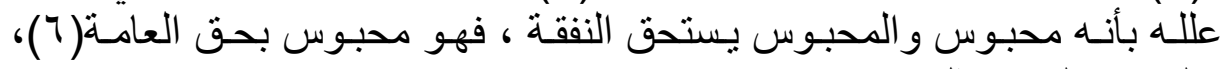
و الكتاب مليء بمثل هذا.

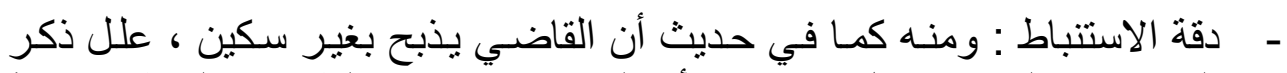
السكين في الحديث وقال :" وهذا لأن السكين تؤثر في الظـاهر و الباطن جميعاً

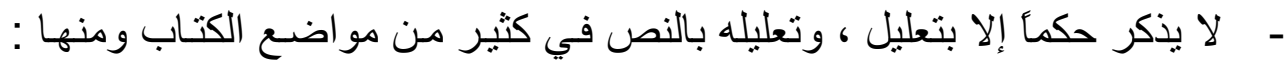

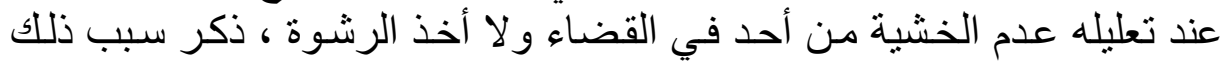
وسرد بعض نصوص الكتاب و السنة ( (l).

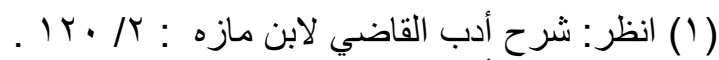

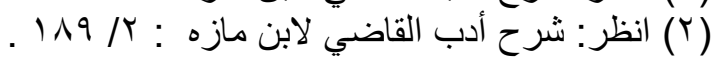

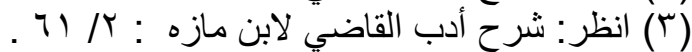

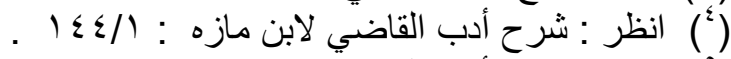

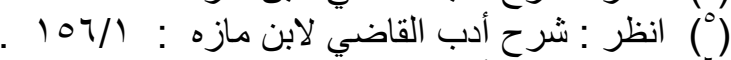

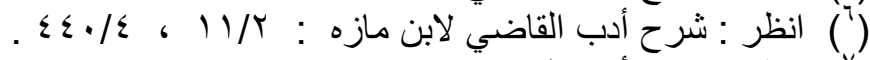

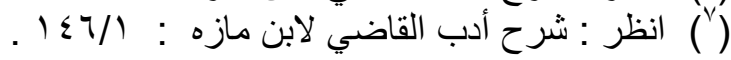




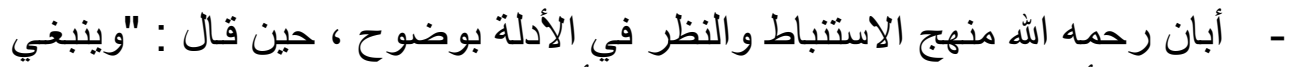

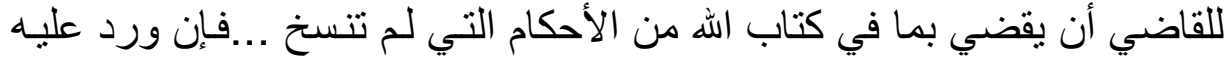

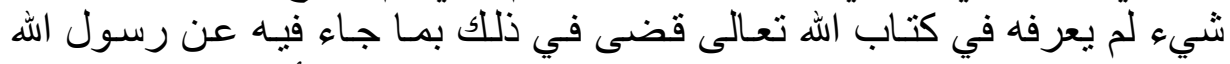

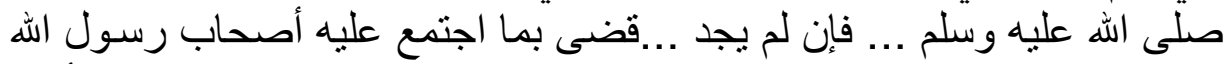

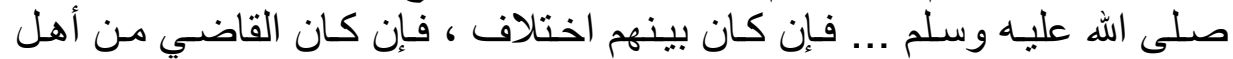

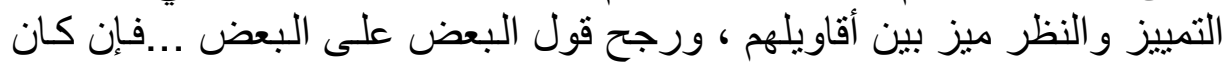

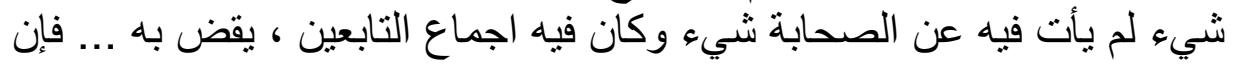

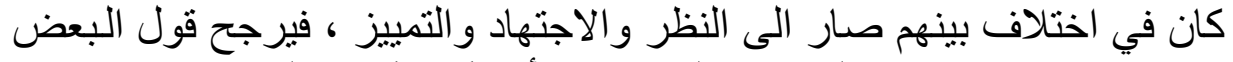

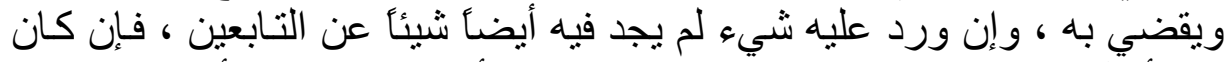

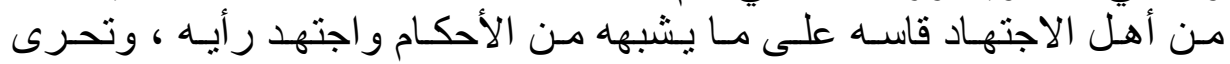

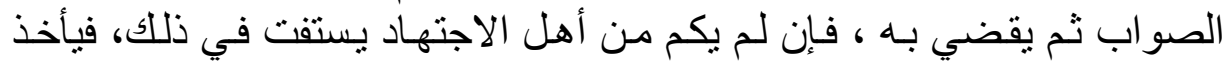
بفتوى المفتي ، ولا يقضي بغير علم "(Y).

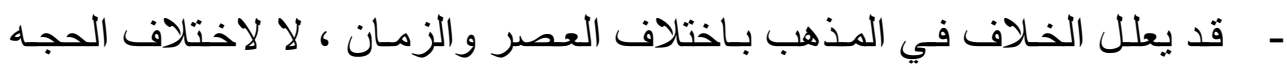

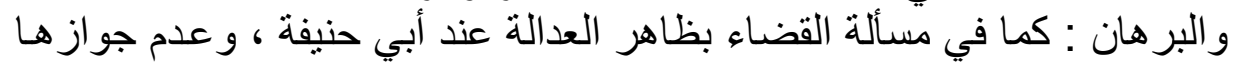

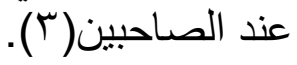

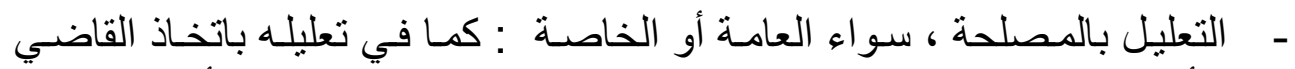

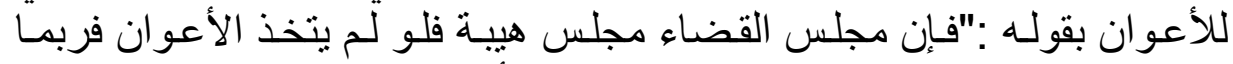

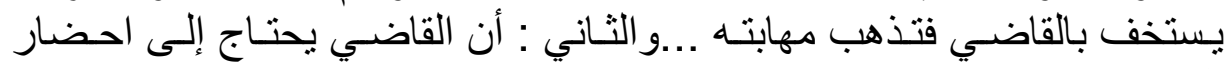

الخصوم ، و لا يمكنه بنفسه" (ع) ).

- قد يستحسن ما الناس عليه في عصره هو على مـا ذكره واستحسنه الخصاف ،

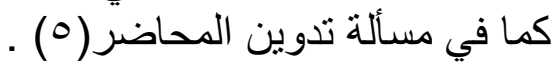

- الفروق الفقهية : يعرض لها كثير أ في شرحه ، وفيها دقة استنيباط عجيب منه ، مما يصلح لو جمع أن يكون رسالة علمية في الفروق (T) ) .

\section{الفرع الخامس: منهجه في ذكر القواعد الفقهية والأصولية والكليات القضائية.}

استعان عبد العزيز بن مـازة في شرحه لأدب الخصاف بجملة عظيمة من القو اعد

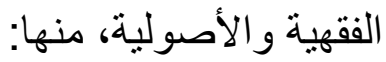

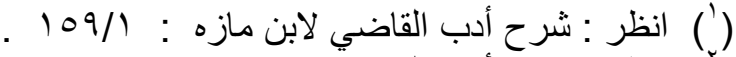

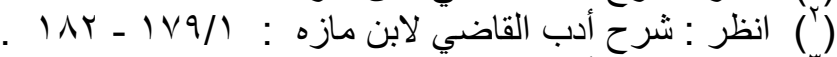

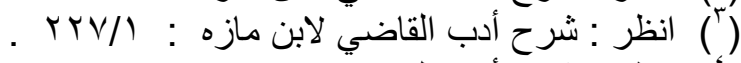

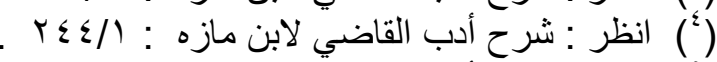

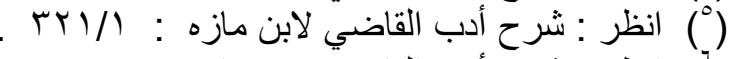

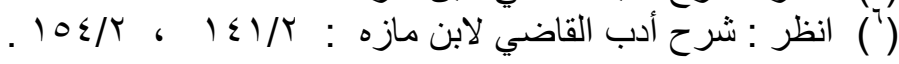


ما بذكر من فو ائد الحديث في الباب الواحد تصلح لأن تكون ضو ابط أو قو اعد أو كلية

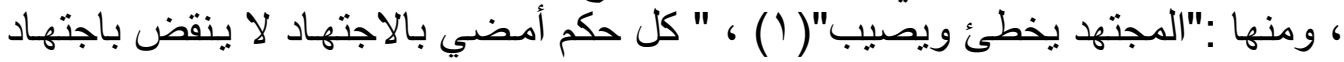
مثله "(r) (Y) (T)

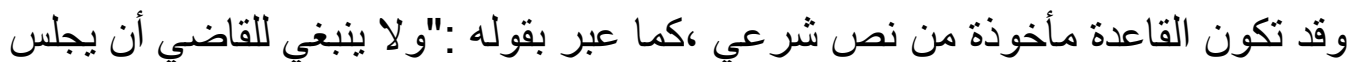

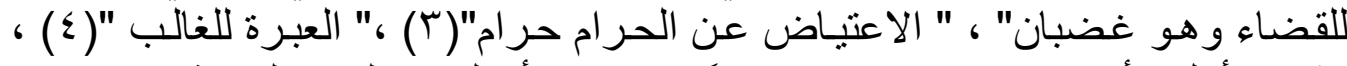

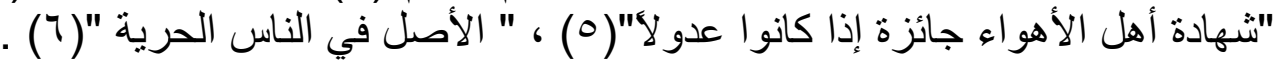
ومن تلك القواعد :

1 ـ الأصل أن من جعل في الثرع القول قوله، فإنما يجعل القول قوله مع يمينه. r - كل حكم يثبت مع الثبهات يجرى فئ فيه الاستحلاف.

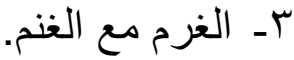
ـ ـ ـ الثابت بالإقر الغ كالثنابت بالمعاينة.

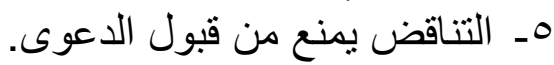
7ـ الثابت بالإقرار لا يعارض الثابت الثابت بالبينة.

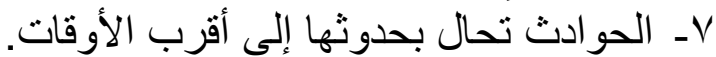
A- البينات شر عت للإثبات لا للابت للنفي.

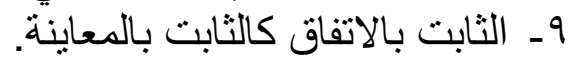

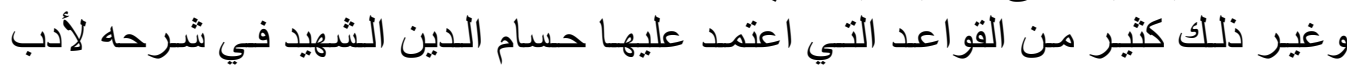

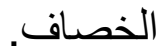

\section{الفرع السادس: منهجه في ذكر التطبيقات القضائية.}

كان بذكر القضية ثم بين حيثيات المسألة، ذاكر ا الحكم فيها، ومن ذلك:

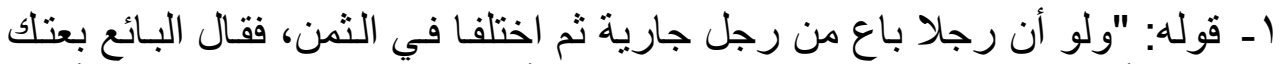

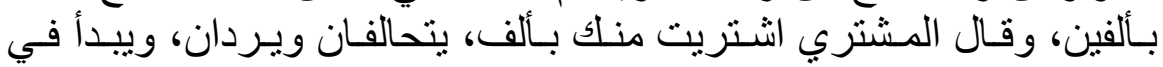

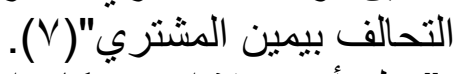

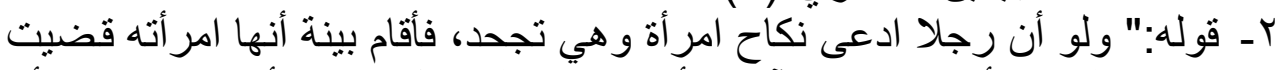

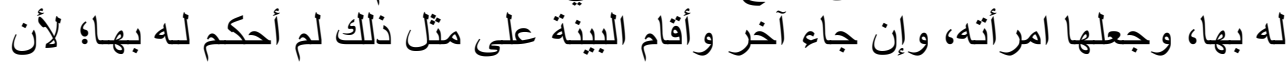

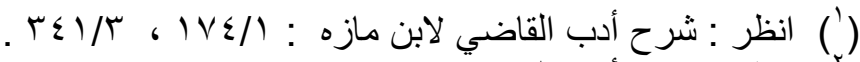

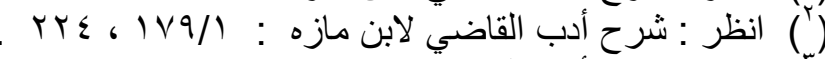

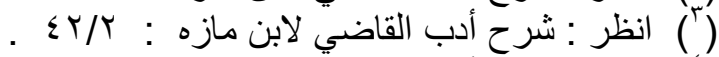

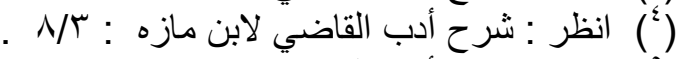

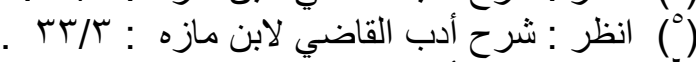

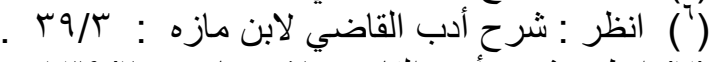

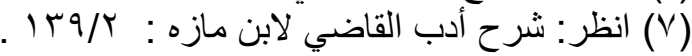


القضاء الأول صـح ظـاهر ا فـلا ينتقضض إلا إذا ظهر الخطـأ بيقين، وذلك أن يوقت

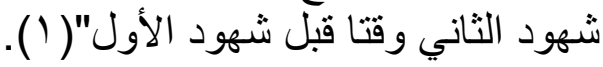

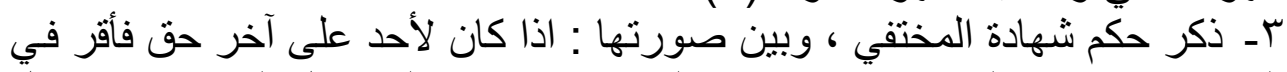

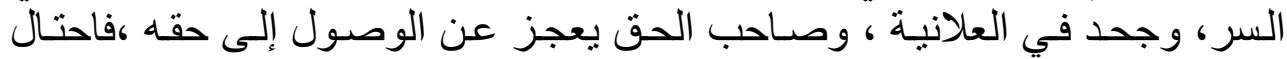

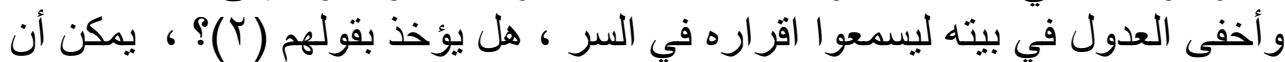

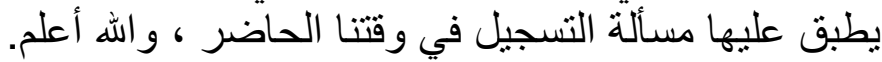

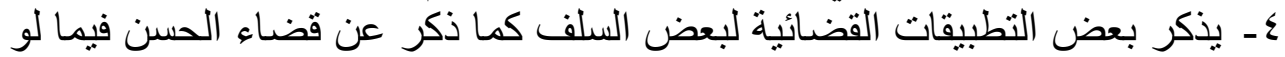

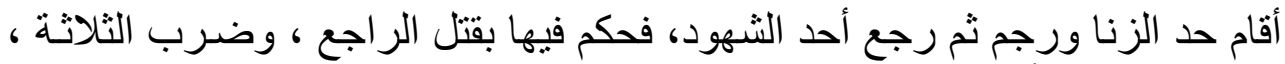

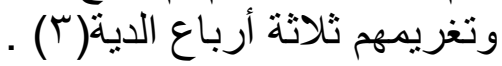

\section{المطلب الرابـر}

\section{أبـرز ما امتناز به الكتناب}

\section{امتاز كتاب ابن مازه في شرحه لأدب القاضي بمزايا عديد، من أهمها ما يلي:}

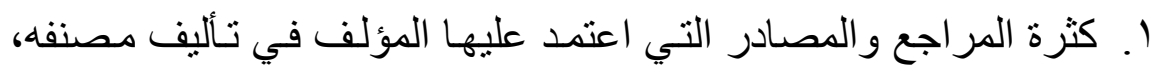

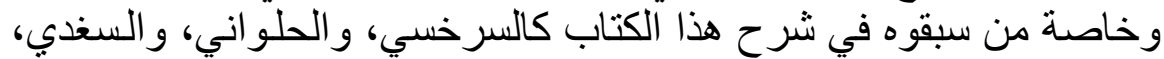

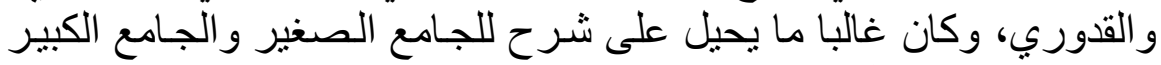
لمحمد بن الحسن الثيباني.

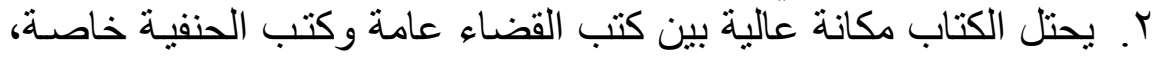

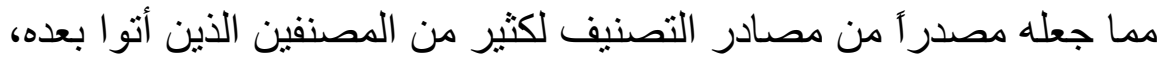

$$
\text { كالسروجي و غيله مهن. }
$$

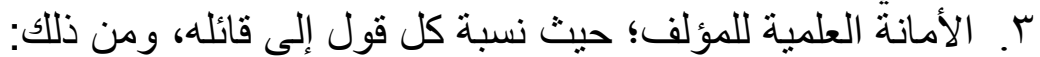

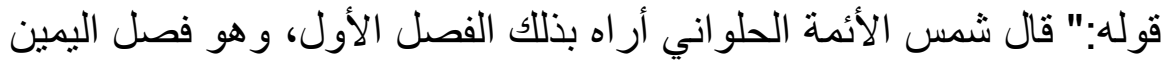

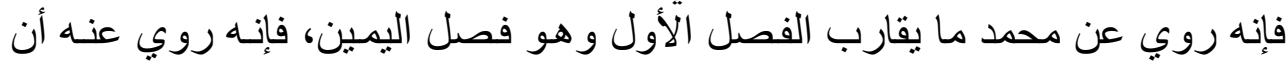

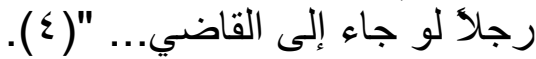
ع. كثرة المسائل التي يذكر ها حسام الدين الشهيد، وهذا يلاحظه كل من طالع هذا

$$
\text { الثرح النفيس. }
$$

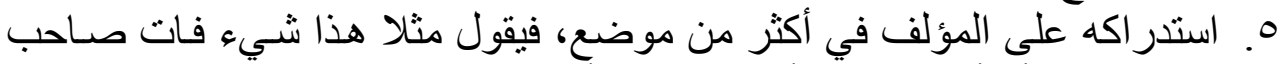

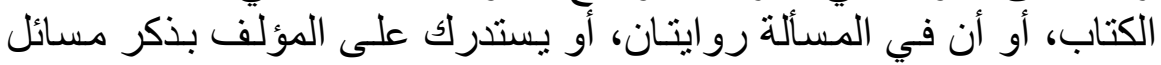

$$
\text { أخرى لم تذكر(ان (0). }
$$

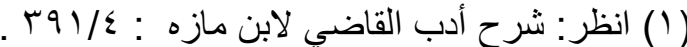

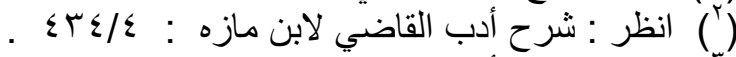

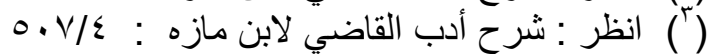

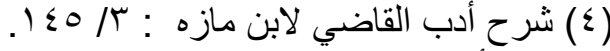

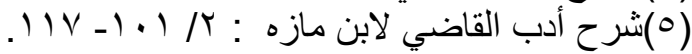


7 7. الكتاب مليء بالنكت القضائية، وهو ما أخبر به حسام الدين في مقدمته على أدب القاضي.

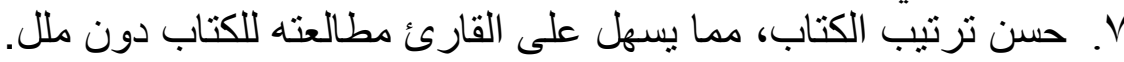

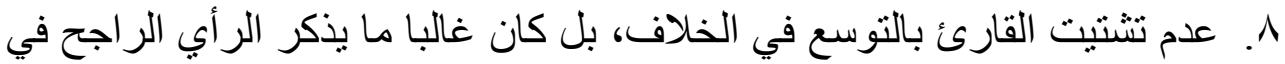

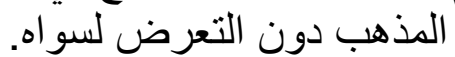
9. استقر اء الشـار ح لجميع الفروع الفقهيـة التي يمكن أن تندرج تحت كل مسألة ذكر ها الخصاف.

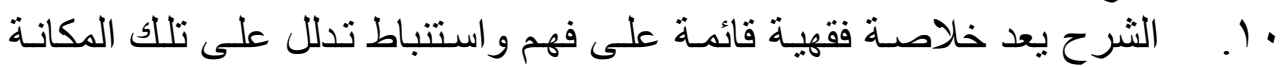

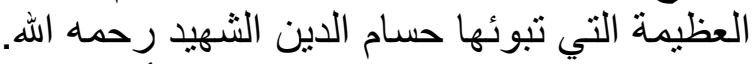

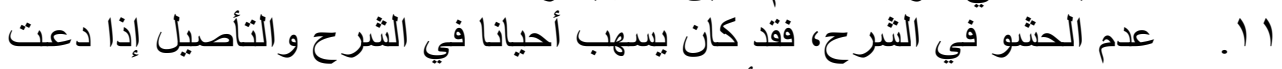

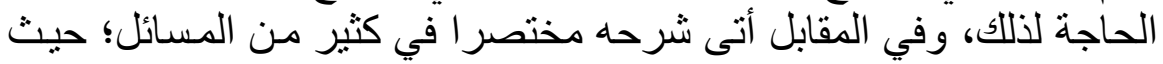

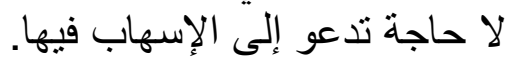

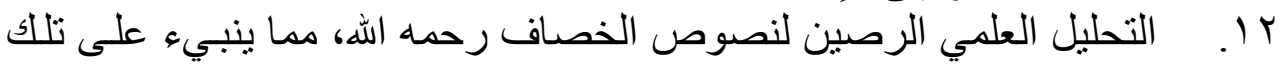
الملكة الفقية الرصينة لالي حسام الدين الثهيد ـرحمه الله. 


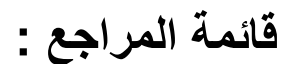

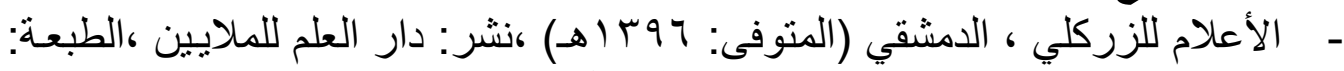

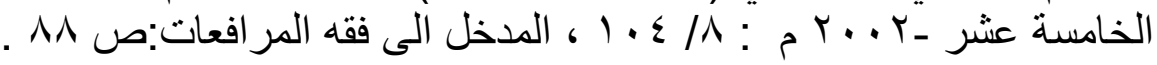

البصائر و الذخائر ، أبو حيان التوحيدي تحقيق محمد السيد عثمان ، دار الكتب

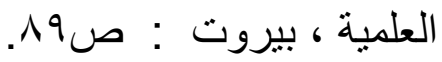

- - تاج التراجم في طبقات الحنفية ،لزين الدين أبو العدل قاسم بن قطلوبغا السودوني

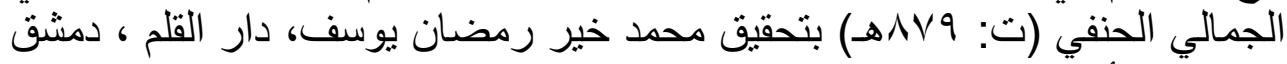

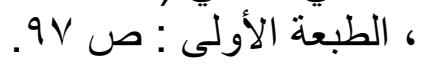

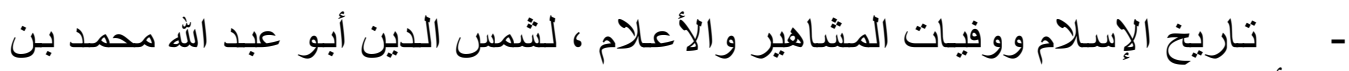

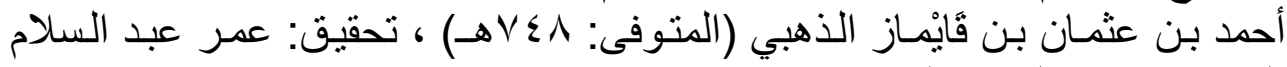

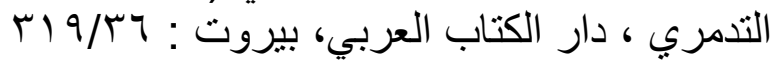

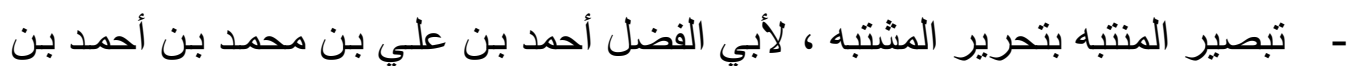

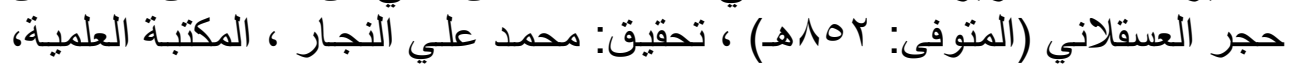

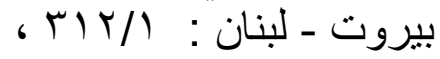

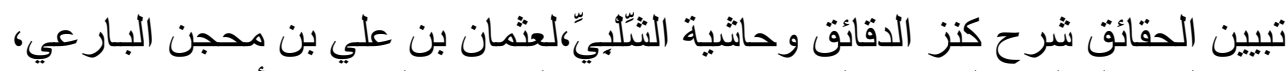

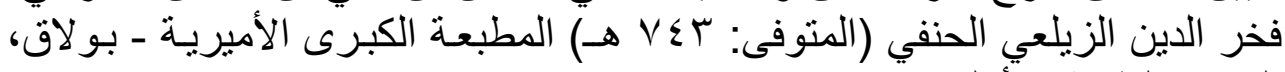

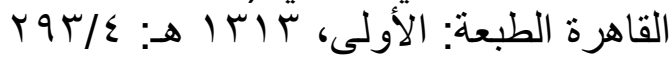

- تقريب الوصـول ، لأبي القاسم محمد بن أحمد الغرنـاطي المـالكي ، حققه محمد

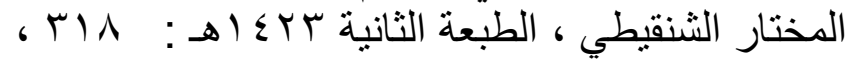

- تهذيب الأسماء و اللغات، محبي الدين يحيى بن شرف النووي، دار الكتب العلمية

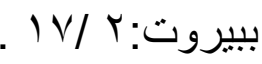

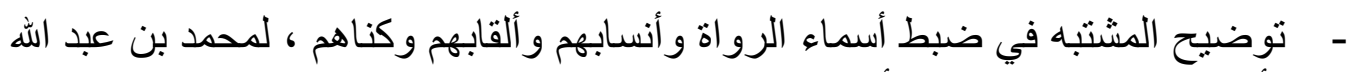

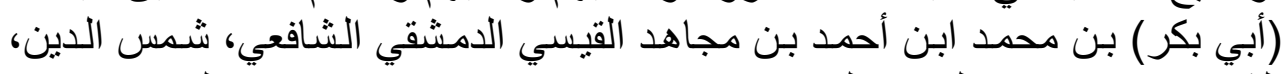

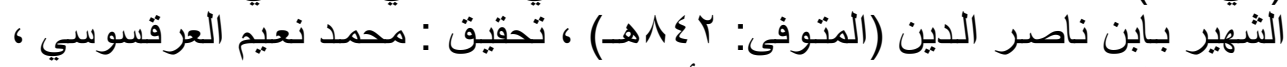

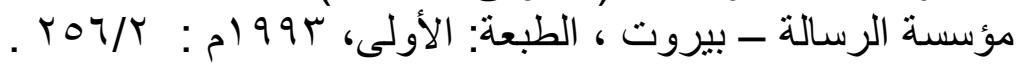

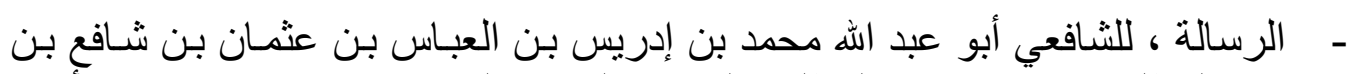

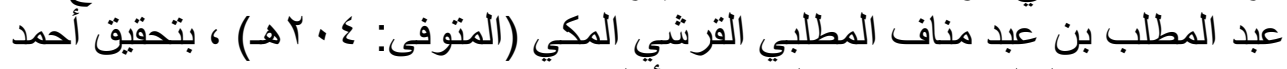

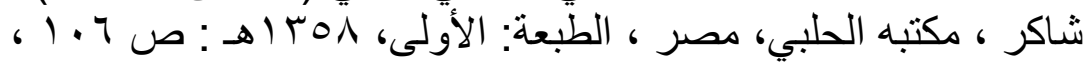

- رشاد الفحول إلي تحقيق الحق من علم الأصول ، لمحمد بن علي بن محمد بن عبد 
الله الشوكاني اليمني (المتوفى: • هب أهـ) ، دار الكتـاب العربـي ، الطبعة الأولى 7

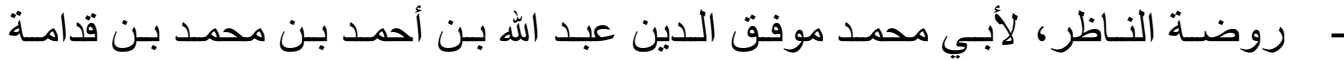

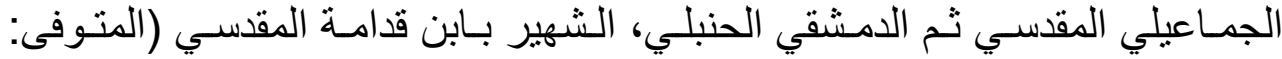

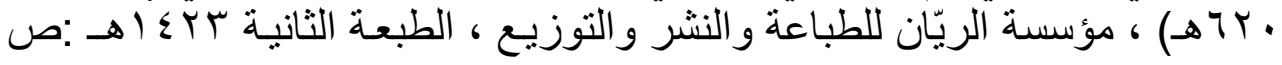

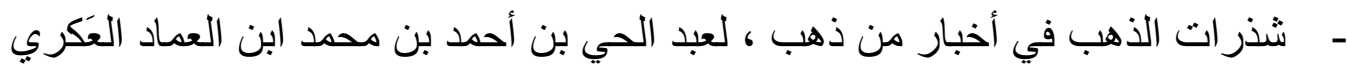

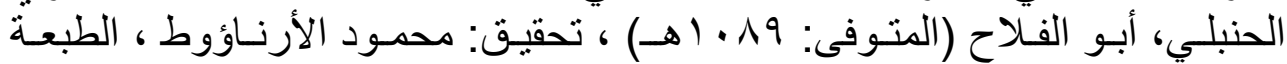

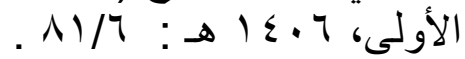

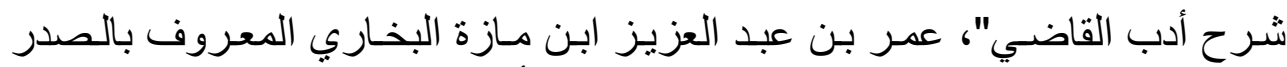

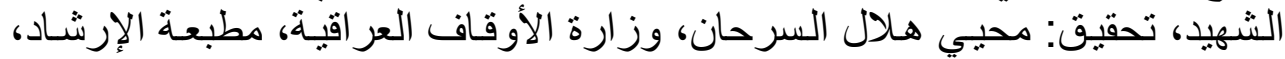

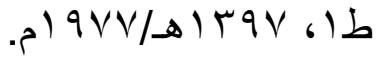

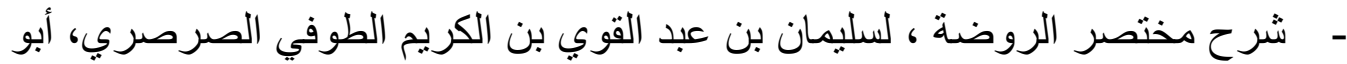

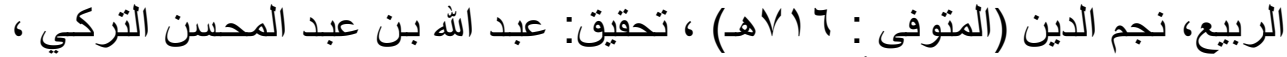

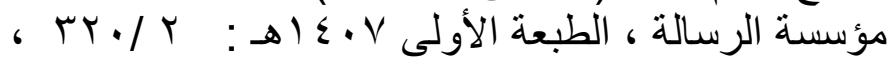

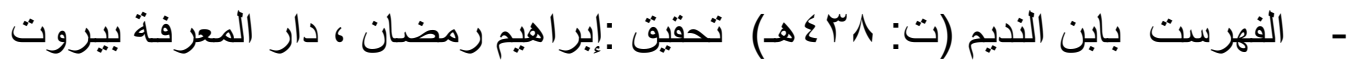

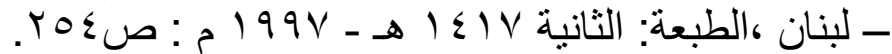

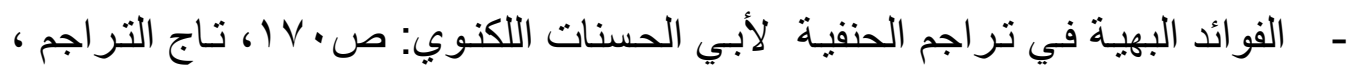

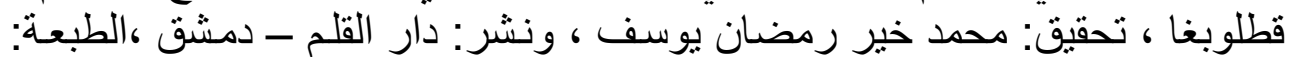

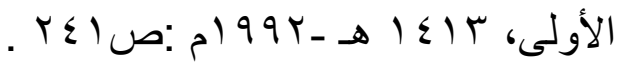

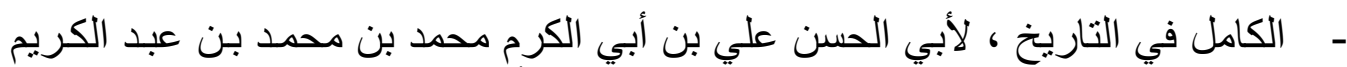

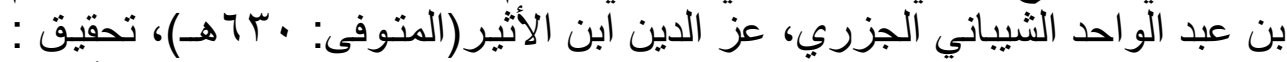

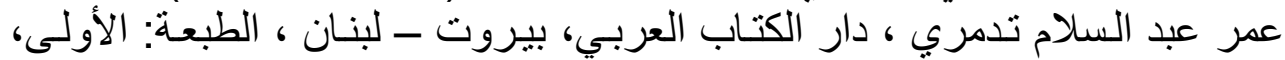
. $17 / / 1: \Delta \leqslant \mid V$

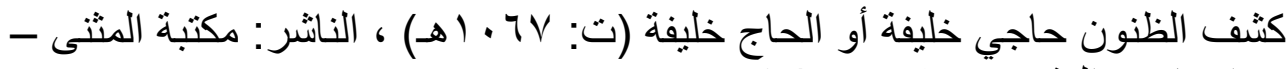

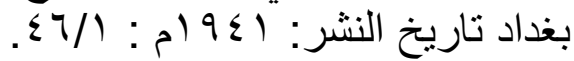

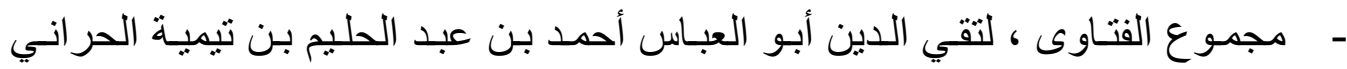

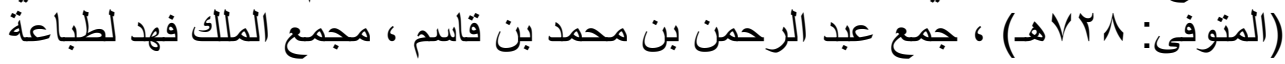

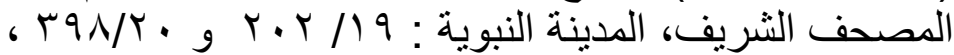


- المدخل إلى فقه المر افعات ، للاكتور : عبداله بن خنين ، دار ابن فرحون : - معجم البلدان لشهاب الدين أبو عبد الله ياقوت بن عبد الله الرومي الحموي (المتوفى:

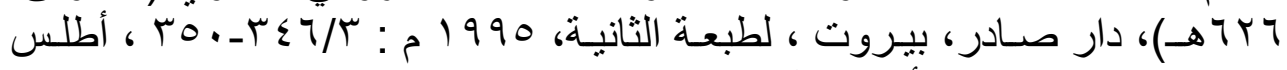

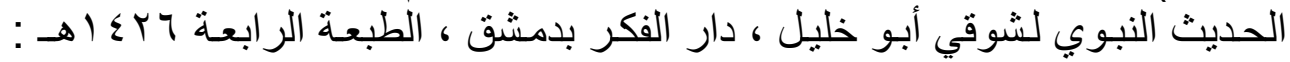
. $7 \leqslant-11$

- معجم المؤلفين ، لعمـر رضـا كحالـة، مكتبـة المثتى - بيـروت، دار إحبـاء التـراث

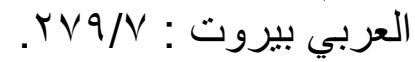

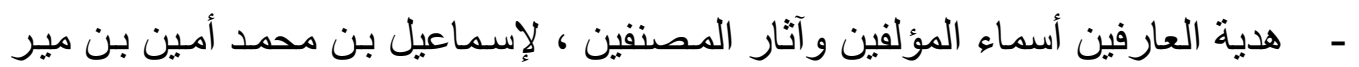

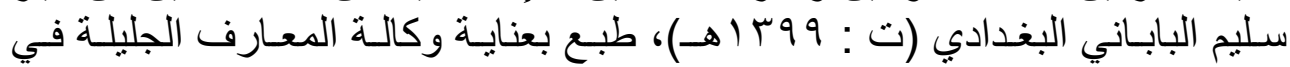

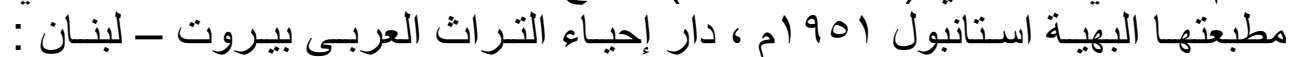
$\varepsilon V / r$ ، $\vee \wedge r / l$

- الواضح في أصسول الفقه ، للدكتور محمد بن سليمان الأشقر ، طبعة دار السلام ، كان

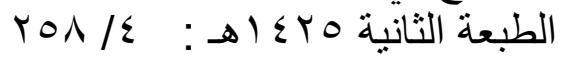

